\title{
Effect of Intelligent Logistics Policy on Shareholder Value: Evidence from Chinese Logistics Companies
}

\author{
Weihua Liu ${ }^{a}$, Siyu Wang ${ }^{a^{*}}$, Yong Lin ${ }^{b}$, Dong Xie ${ }^{c}$, Jiahui Zhang ${ }^{a}$ \\ a. College of Management and Economics, Tianjin University, Tianjin, 300072, China \\ b. Systems Management and Strategy Department, Business School, University of Greenwich, \\ SE10 9LS, UK \\ c. Department of Industrial Engineering, Tsinghua University, Beijing, China

\section{Weihua Liu} \\ Ph.D , Professor \\ College of Management and Economics, Tianjin University, \\ No.92, Weijin Road, Nankai District, Tianjin, 300072, China \\ E-mail: lwhliu@tju.edu.cn
}

\section{Siyu Wang}

College of Management and Economics, Tianjin University, No.92, Weijin Road, Nankai District, Tianjin, 300072, China Email: wangsiyu916@tju.edu.cn

\section{*Corresponding author}

\section{Yong Lin}

Systems Management and Strategy Department, Business School, University of Greenwich, SE10 9LS, UK

Email: y.lin@gre.ac.uk

\section{Dong Xie}

Department of Industrial Engineering, Tsinghua University, Haidian District, Beijing, China

E-mail: xd3007209203@163.com

\section{Jiahui Zhang}

College of Management and Economics, Tianjin University, No.92, Weijin Road, Nankai District, Tianjin, 300072, China

Email: tju_jiahuizhang@163.com

\section{Conflict of Interests}

The authors declare that there is no conflict of interests regarding the publication of this article. 


\section{ACKNOWLEDGEMENT}

This research was funded by National Key R\&D Program of China (grant number No. 2018YFB1601400) and by Major Program of the National Social Science Foundation of China (grant number No. 18ZDA060). The reviewers' comments are also highly appreciated. 


\title{
Effect of Intelligent Logistics Policy on Shareholder Value: Evidence from Chinese Logistics Companies
}

\begin{abstract}
This paper empirically investigates the effects of intelligent logistics policies (ILPs) on shareholder value of the 149 listed logistics companies from 20132018 in China. The research shows that ILPs will result in a positive stock market reaction, and this effect is increasing along with the increase of policy contents related to intelligent logistics or the decrease of company service breadth. The market reaction will be affected by the way that policies are issued and type of company. The logistics service providers are more positive when their financial performances are better, while the opposite result is observed for logistics equipment manufacturers.
\end{abstract}

Key words: Intelligent logistics; Government policy; Empirical research; Stock market reaction

\section{Introduction}

Along with the fourth revolution of science and technology, the world has stepped into a new era of intelligence, which has led to a wave of technology research and implementation, such as smart factories, smart production and intelligent logistics (Tjahjono et al., 2017). Many global companies are developing intelligent logistics for the increasing demand of today's global supply chains and transportation systems to provide customers with resource-efficient, secure, sustainable, and timely services anytime and anywhere (Jabeur et al., 2017). For example, intelligent logistics brings Cainiao Network one step closer to the goal of delivering products within 72 hours globally (Yang, 2019). JD.com has used the unmanned aerial vehicle to deliver packages in Xi'an city, China (Fan, 2019). DHL has set up an innovation center to apply autonomous technologies, Internet of things and other intelligent technologies to logistics business (Li, 2015). Uckelmann (2008) first defined intelligent logistics, which is a new mode driven by emerging technologies, such as big data, Internet of Things, and cloud computing, and realizing industry-wide connectivity, sharing and symbiosis through automation, visualization and informatization in the operation of logistics services. Intelligent logistics is a special system supported by advanced information technology to realize system perception, comprehensive analysis, timely processing and self-adjustment in various procedures of logistics, such as 
warehousing, distribution, and information service. It has the characteristics of automation, intelligence, visualization, networking, flexibility, etc., and thus can promote manufacturing, retail and e-commerce in an all-around way. The biggest difference between intelligent logistics and traditional logistics is that intelligent logistics can plan, manage or control logistics operations (inventory, transportation or order management) in a more intelligent way, thus making the whole process of logistics visible, perceptible and real-time adjustable to improve the economic efficiency of the whole industry (McFarlane et al., 2016). In this paper, we will select policy samples according to these characteristics of intelligent logistics.

Intelligent logistics policies (ILPs) are policies issued by the government to promote the development of the intelligent logistics industry. These logistics policies cover a wide range of subjects and usually involve the demand, supply, facilities and equipment, information technology, management system and other aspects of intelligent logistics. For example, for the demand aspect of intelligent logistics, the policy "Guiding Opinions on Promoting the Intelligent Development of Transportation Informatization" issued by the Ministry of Transport of PRC (MOT) highlighted that "intelligent logistics drives the rapid growth of the transportation information consumption scale (MOT, 2013)". For the supply aspect of intelligent logistics, The National Development and Reform Commission of PRC (NDRC) and MOT jointly launched the policy "Promoting 'Internet +' Convenient Transportation to Promote the Development of Intelligent Transportation", and it referred to "the development of intelligent logistics as the guide, enhancing the industry's innovation ability, providing diversified products and meeting diversified needs (NDRC, 2016b)." For the facilities and equipment aspect of intelligent logistics, the NDRC launched the policy “"Internet +' Efficient Logistics Implementation Opinions", and it referred to "encouraging the development of logistics for robot technology, promoting the application of robots in the logistics field, promoting breakthrough technology of robot image recognition, high-density storage mechanical arm picking, voice picking etc., and developing multi robot applications in the warehouse (NDRC, 2016a)." In the information technology aspect of intelligent logistics, the policy "Medium and long-term planning for the development of logistics industry (2014-2020)" issued by the State Council mentioned that we should "strengthen the application of Beidou navigation, Internet of things, cloud computing, big data, mobile Internet and other advanced information technologies in the field of logistics (State Council, 2014)." In the management system aspect of intelligent logistics, the policy "Notice on 
Forwarding the Special Action Plan for the Reduction and Efficiency of Logistics Industry (2016-2018)" issued by the General Office of the State Council referred to "establishing a standardized, information-based, networked, intensive and intelligent modern logistics service system (State Council, 2016)".

As a new form of logistics industry, intelligent logistics has attracted the attention of many investors. The release of ILPs may have an impact on the relevant enterprises, which may affect the shareholder value of logistics listed companies. However, the ILPs have not been studied quantitatively. On the one hand, McFarlane et al. (2016) and Jabeur et al. (2017) both thought that government policies are very important for intelligent logistics, whether and how government policies promote the intelligent logistics and whether they can get the attention of the market, especially the stock market, has not been studied. On the other hand a large number of studies have focused on changes in performance caused by the issuance of government policies (Brogaard and Detzel, 2015; Kaustia et al., 2016), and many articles have used event study to study logistics and supply chain management (Hendricks and Singhal, 2003; Lin and Su, 2013; Jacobs et al., 2010). However, the stock market reaction caused by the release of logistics policies has not been studied. Moreover, most studies generally analyze the policy quality and government behavior from the financial indicators such as stock index (Asongu, 2012; Kaustia et al., 2016), ignoring the impact of characteristics of various companies on the stock market.

In order to fill the above research gaps, this paper focuses on the relationship between ILPs and the shareholder value of logistics listed companies. We will examine three important questions. First, will ILPs have an impact on listed logistics companies? Second, how do different release modes of ILPs affect the policy effect? Third, how are different types of companies affected by ILPs?

To answer these three questions, this paper empirically investigates the effects of ILP on shareholder value of the 149 listed logistics companies from 2013-2018 in China and provides suggestions for governments and logistics companies in the development of intelligent logistics. We refer policy as to a government document released to the public, which not only guides enterprises but also provides market investors with information on the industry. The stock market and stock price are heavily influenced by publics' behaviors (Brogaard and Detzel, 2015; Kaustia et al., 2016). Therefore, shareholder value is a very intuitive indicator to measure the effectiveness of the policy. In existing studies, many papers analyzed the stock abnormal return to discuss effects of some events (Hendricks et al., 2009; Lam et al., 
2016; Ding et al., 2018). In this paper, we study the short-term market reaction of ILPs. On the one hand, the short-term market reaction is the initial reaction to policy, which is very important to measure the policy effect. Therefore, the study of shortterm market reaction is of great significance to the accuracy of the policy, and it can also help the government's decision-making. On the other hand, ILPs have only been published in recent years, and long-term performance studies generally require three years performance data at least (Corbett et al., 2005; Hendricks and Singhal, 2005). It is still unable to fully measure the long-term performance of companies after the release of ILPs. Therefore, this paper discusses the short-term market reaction of ILPs and obtains many important conclusions.

For the first question, we find that the ILP will result in a positive stock market reaction and the mean (median) abnormal return on the event day is $0.625 \%(0$. $352 \%$ ). For the second question, which is focused on the release mode, we find that the market reaction is more positive with increased policy contents related to intelligent logistics. Surprisingly, the General Office of the State Council, which is the leading agency, has a lower impact than its subordinate ministries (e.g., NDRC). Moreover, a centralized release will hinder the positive effect of policies on the market. For the third question, which is focused on the company factors, we find that the reaction decreases as the companies' service breadth increases. In addition, stateowned logistics companies are more active than other companies. The relationship between the firm's financial performance and its business type is significant. For a logistics service company(LSC), when its prior financial performance (PFP) is better, its shareholder value will be more positively affected by the intelligent logistics policy than that when its PFP is worse; and for a Logistics Equipment or System Manufacturing Company (LESMC), when its PFP is worse, its shareholder value will be more positively affected than that when its PFP is better.

Overall, our study makes three main contributions. First, to our best knowledge, this study is the first to analyze the effects of ILPs on the stock market by the event study method. We investigate the short-term market reaction of the companies during the event windows of policy release, providing a new perspective for studying and evaluating policies. Second, from the perspective of government and companies, this study discusses the influence of various factors such as policy release modes and company types on the market reaction of logistics policies, which provides a model to study the effects of industry policies on the stock market. Third, the conclusions of this paper confirm and enrich some research theories. For example, institutional 
theory holds that the functions of government departments are different. It's commonly known that departments with higher power have greater influence on social economy (Kong, 2019). We find that the General Office of the State Council, which is the leading agency, has a lower impact than its subordinate ministries. This conclusion shows that institutional theory has particularity in the economy. The ministries with less power but closer responsibilities may have more influence in certain industries. In addition, we find that the LSCs are more positive when their financial performances are better, while the opposite result is observed for LESMCs. This phenomenon verifies the interaction effects. This theory holds that companies with different performance may have opposite reactions to the same thing (Jacobs and Singhal, 2014; Li et al., 2019a). Our research shows that the interaction effects are still valid in the stock market reaction of policies, which expands the scope of this theory.

The remainder of this paper is organized as follows. Section 2 presents a review of the existing literature on intelligent logistics, policies and event studies. Section 3 introduces the research methods and the basis and process of sample selection. Section 4 proposes the hypotheses. Section 5 presents the analysis results and model expansion. Section 6 discusses the conclusions and the significance of management. Section 7 gives a brief account of the shortcomings of the article and the future research directions.

\section{Literature review}

The literature review focuses on three aspects: intelligent logistics, government policies and the stock market, event studies of logistics and supply chain management. We compare this study with the most relevant literature to address the location of the paper in the area.

\subsection{Intelligent Logistics}

Some researchers consider intelligent logistics as a system with management and coordination, adaptation, optimization and scheduling, monitoring and intelligent supervision and direct control layers dedicated to dynamic, stochastic, multicriteria intelligent logistics decision problems (Adamski, 2011). Kirch et al. (2017) thought that intelligent logistics will achieve the efficient organization of logistics and information flows within the transportation network across companies or across industries, and it is an inevitable trend in the development of modern logistics. The current research has focused on technologies in intelligent logistic to improve efficiency, such as Intelligent Transportation System and Physical Network 
(Montreuil, 2011), RFID Technology (Kirch et al., 2017), Big Data Analysis (Choi et al., 2018; Govindan et al., 2018). However, most of the research focused on technological innovation. The research on intelligent logistics from the perspective of management is still relatively scarce.

Governmental policymaking is one of the pillars of intelligent logistics besides the innovative technology (Jabeur et al., 2017). Many scholars have studied how the government develops intelligent logistics. On the one hand, from the perspective of government management, Magalhaes et al. (2017) found that the government can support logistics enterprises through data opening. On the other hand, from the industry demand, Docherty et al. (2018) showed that smart mobility needs long-term supervision by the government by case study. Li et al. (2019b) discussed policymaking on automated vehicles. However, the researches on intelligent logistics policy have been only based on case studies, lacking the data studies. This paper will use statistical methods to study how policies affect intelligent logistics from the perspective of government and enterprise management to enrich empirical research on intelligent logistics.

\subsection{Government Policies and the Stock Market}

Many researchers have studied the effects of policies on stock market and corporate performance. However, the topics of research are still limited. Most studies investigated the effects of policy uncertainty on the stock market from both modeling (Pastor and Veronesi, 2012) and empirical (Brogaard and Detzel, 2015; Kaustia et al., 2016) perspectives. Other studies have discussed policy quality. For example, Asongu (2012) discussed the effects of government effectiveness, political stability and legal origins on the stock market. His research demonstrated a significant positive association between stock market performance measures and the quality of government institutions. Mosley and Singer (2008) studied legal traditions, levels of democracy and stock market valuations. These studies only analyzed the effects of political behavior on the economic field, but they had not discussed different industry policies.

Many studies on industry policies are mainly focused on oil (Kang and Ratti 2013; Gao et al., 2019), finance (Raza et al., 2012; Chatziantoniou et al., 2013; Aziza, 2010), environment (Thomas, 2001). In terms of manufacturing and service industries, Brandon-Jones et al. (2017) studied the shareholder wealth effects of reshoring decisions in the US. However, in the field of logistics industry, the shareholder value effects of logistics policies have not been studied. Therefore, this 
paper attempts to remedy this gap.

\subsection{Event Studies in Logistics and Supply Chain Management}

Logistics and supply chain management plays a vital role in generating shareholder value through the mechanisms of revenue growth, operating cost reduction, and efficient use of fixed and working capital (Martin and Lynette, 1999). Researchers have conducted various empirical studies to analyze the connection between logistics \& supply chain management and shareholder value, among which the event study method represents one of the most popular methodologies adopted in the literature (Ding et al., 2018).

The event study method is applied to different topics of logistics and supply chain management, such as green logistics and supply chain (Klassen and McLaughlin, 1996; Jacobs et al., 2010), supply chain disruption (Hendricks and Singhal, 2003), product recall (Zhao et al., 2013) and logistics and supply chain service quality (McGuire and Dilts, 2008; Lin and Su, 2013). However, the topics of current event study articles are generally focused on the business level of enterprises. For example, Kavussanos \& Marcoulis (1997) undertook a comparative analysis of the stock market perception of risk of U.S. listed water transportation and other transport sectors such as air transportation, rail transportation, trucks. Many studies have examined the effects of deregulation (Lepak, 1997) or pollution (Seufert et al., 2017) on stock price movements for the airline industry. Few articles have used the event study method to explore government policy issues or the relationship between logistics policy and shareholder value. Therefore, this paper will analyze the impact of different intelligent logistics policies on shareholder value using the event research method to provide suggestions for the development of intelligent logistics for both the government and enterprises.

\subsection{Summary}

According to the above literature review, we find that intelligent logistics has become a research hotspot. Researchers have studied government policies through the stock market and have discussed logistics problems by second-hand data. But logistics policies and intelligent logistics have not been studied by second-hand data and event study method. Table 1 shows how our study differs from the most relevant literature. 
Table 1 The differences between our study and relevant literature

\begin{tabular}{|c|c|c|c|c|c|}
\hline & $\begin{array}{l}\text { Brogaard and } \\
\text { Detzel (2015) }\end{array}$ & $\begin{array}{l}\text { Brandon- } \\
\text { Jones et al. } \\
\text { (2017) }\end{array}$ & $\begin{array}{l}\text { Choi et al. } \\
\text { (2018) }\end{array}$ & $\begin{array}{l}\text { Docherty et } \\
\text { al. (2018) }\end{array}$ & This study \\
\hline Topic & Finance & Supply chain & $\begin{array}{l}\text { Logistics and } \\
\text { supply chain }\end{array}$ & $\begin{array}{l}\text { Logistics and } \\
\text { supply chain }\end{array}$ & $\begin{array}{l}\text { Logistics and } \\
\text { supply chain }\end{array}$ \\
\hline Method & $\begin{array}{l}\text { Second-hand } \\
\text { data }\end{array}$ & $\begin{array}{l}\text { Second-hand } \\
\text { data }\end{array}$ & Case study & Case study & $\begin{array}{l}\text { Second-hand } \\
\text { data }\end{array}$ \\
\hline $\begin{array}{l}\text { Intelligent } \\
\text { logistics }\end{array}$ & $\mathrm{x}$ & $\mathrm{x}$ & $\sqrt{ }$ & $\sqrt{ }$ & $\sqrt{ }$ \\
\hline Policy & $\sqrt{ }$ & $\sqrt{ }$ & $\mathrm{x}$ & $\sqrt{ }$ & $\sqrt{ }$ \\
\hline $\begin{array}{l}\text { Government } \\
\text { factor }\end{array}$ & $\sqrt{ }$ & $\mathrm{x}$ & $\mathrm{x}$ & $\sqrt{ }$ & $\sqrt{ }$ \\
\hline $\begin{array}{l}\text { Company } \\
\text { factor }\end{array}$ & $\mathrm{x}$ & $\sqrt{ }$ & $\sqrt{ }$ & $\mathrm{x}$ & $\sqrt{ }$ \\
\hline
\end{tabular}

\section{Methodology}

In answering the research questions, we adopt the event study methodology for this research. The below sections will justify in detail and describe the sample collection process, including the samples selected from two parties, namely, government policies and logistics companies, and explain the establishment of the sample database.

\subsection{Event Study Methodology}

This study employs the event study methodology to estimate the market reaction to relevant ILPs. The event study method is a statistical method proposed by Brown and Warner (1985). Generally, the market reaction is estimated by the magnitude of the abnormal returns associated with the event. Abnormal returns refer to the difference between the actual stock return and the expected return on the event day.

\subsubsection{Methods for Estimating the Abnormal Stock Returns}

For each sample, calendar time is converted to event time according to the following rules. The date on which the policy was published is the event day or day 0 . If the date of the policy is not a trading day, then the next trading day is set as day 0 . The trading day before day 0 is day -1 , the trading day after day 0 is day 1 , etc. Furthermore, if the policy is released after 3:00 pm, then the stock market could not react to the policy until the next trading day (because it is closed after 3:00 pm). If so, 
then the trading day after the day of publication is day 0 .

In this paper, we estimate abnormal returns using the Market model, which is the most commonly used model in event studies (Brown and Warner 1985). The Market model posits a linear relationship between the stock return and the return on the market portfolio (market return) over a given time period:

$$
R_{i t}=\alpha_{i}+\beta_{i} R_{m t}+\varepsilon_{i t}
$$

where $R_{i t}$ is the Day $t$ return of stock $i ; R_{m t}$ is the Day $t$ market return; $\alpha_{i}$ is the intercept of the relationship for stock $i ; \beta_{i}$ is the systematic risk (or beta) of stock $i$, which measures the sensitivity of stock $i$ 's return to the market return; and $\varepsilon_{i t}$ is the error term for stock $i$ on Day $t$. Stock market movement accounts for a portion of stock $i$ 's return and is represented by the term $\beta_{i} R_{m t}$ (the systematic component of stock $i$ return). The portion of the return that is unexplained by market movements is $\varepsilon_{i t}$ (the idiosyncratic component of stock $i$ return).

We estimate the expected return for each sample firm using data from a 200-day estimation period that begins on Day -210 and ends on Day -11. This estimation window is very common in the event studies (Hendricks et al., 2009; Lam et al., 2016; Ding et al., 2018). We end the estimation period 2 weeks (10 trading days) prior to the event day to shield the estimates from the effects of the policy and to ensure that any nonstationarity in the estimates is not an issue. Moreover, for Policy A, if another Policy B was issued during the estimated period of Policy A, to avoid the interaction between these two policies, we exclude the market returns of Policy B and do not take it as the estimation period. In estimating the parameters, we require that a firm must have a minimum of 40 stock returns during the estimation period of 200 trading days, which is consistent with other studies that use the same estimation period (Jacobs and Signhal, 2014; Hendricks et al., 2014). We calculate least squares estimate based on the 200-day data to obtain $\hat{\beta}_{i}$ and $\hat{\alpha}_{i}$.

During the event period, the expected return of stock $i$ on day $t$ is

$$
\hat{\mathbf{R}}_{i t}=\hat{\alpha}_{i}+\hat{\beta}_{i} R_{m t}
$$

The abnormal return of stock $i$ on day $t$ is

$$
A_{i t}=R_{i t}-\hat{R}_{i t}
$$

$\mathrm{N}$ is the sample size. The mean abnormal return for Day $t$ is given by the following:

$$
\bar{A}_{t}=\sum_{i=1}^{N}\left(A_{i t} / N\right)
$$




\subsubsection{Robustness Test}

Because ILPs may have an impact on the stock price of many logistics companies, the $R_{m t}$ of day 0 may also be affected. Therefore, before calculating the abnormal return of the sample, we calculate the market index of the company excluding the sample and check its correlation with the market index of the company including the sample to verify whether $R_{m t}$ is affected.

Meanwhile, we are estimating the abnormal returns for multiple firms with an event on the same calendar day, which can cause cross-sectional dependence in abnormal returns across the sample firms. If such cross-sectional dependence is not adjusted for, then the standard deviation may be underestimated and the magnitude of the test statistics may also be overestimated. In response to this, we use the clustered version of the t-test by Brown and Warner (1985) that adjusts for cross-sectional dependence. We compute the mean abnormal return A for the 200-day estimation period as

$$
\overline{\bar{A}}=\frac{\sum_{t=-202}^{t=-3} \overline{A_{t}}}{200}
$$

We then estimate the standard deviation from the mean daily abnormal returns for the 200-day estimation period as

$$
\hat{S}\left(\overline{A_{t}}\right)=\sqrt{\sum_{t=-202}^{t}=-3\left(\overline{A_{t}}-\overline{\bar{A}}\right)^{2}} / 199
$$

We calculate the Day $t$ test statistic $T S_{t}$ as

$$
\mathrm{TS}_{t}=\overline{A_{t}} / \hat{S}\left(\overline{A_{t}}\right)
$$

Next, we use two nonparametric tests to check whether the outliers affect the results, as seen in Jacobs and Singhal (2014). The first is the Wilcoxon signed-rank test, which is used to assess whether the median of the abnormal returns is significant. The other is the binomial sign test, which is used to assess whether the probability of positive returns is significantly greater than $50 \%$. These two tests are very common in event study papers published in top journals (Jacobs and Singhal, 2014; Hendricks et al., 2014), and they are performed to demonstrate that the positive market reaction is not caused by some extreme values.

Finally, this paper studies stock market reaction by event study, which is different from other empirical research by questionnaire survey. We are unable to interview some companies to verify the validity of the findings. Because the shareholder value effects of logistics policies are reflected in the price factor and the 
price is the equilibrium among many suppliers and demanders. It is difficult to verify the validity of the results by interviewing an investor. In addition, the existing event studies are also all based on statistical methods, without interview survey (Hendricks and Singhal, 2005; Jacobs and Singhal, 2014; Xia et al., 2016). Therefore, this paper only uses the second-hand data for empirical research.

\subsection{Policy Samples}

\subsubsection{Selection of the government department}

First, the data sample is obtained from Chinese government departments. According to the official statement of the Chinese government website, the State Council of the People's Republic of China, namely, the Central People's Government, is the executive department of the highest state power and the highest state administrative department. Under the State Council, an office has been set up to manage state administrative affairs, named the General Office. Because the State Council and the General Office are similar leaders and have a common website to publish policy, we classified the State Council and the General Office as one class in the following test. The policies in this paper are all documents published by the State Council, the office and its subordinate organizations. Due to the large number of departments and institutions under the State Council, in addition to those policy documents issued by the State Council and the General Office, we also ensured that the selected departments and institutions are directly related to the logistics industry according to [2005] No.288 "the Circular of the National Development and Reform Commission on Establishing the Inter-ministerial Joint Conference System of Modern Logistics Work". These departments are as follows: National Development and Reform Commission (NDRC), Ministry of Industry and Information Technology (MIIT), Ministry of Public Security (MPS), Ministry of Transport (MOT), Ministry of Commerce (MOC), Ministry of Finance (MOF), General Administration of Customs (GACC), Civil Aviation Administration of China (CAAC), State Post Bureau (SPB), Standardization Administration (SAC), National Railway Administration (NRA), State Taxation of Administration (STA), and China Federation of Logistics \& Purchasing (CFLP). It should be noted that the China Federation of Logistics and Purchasing is an industry association and does not have the power to issue policies, although it does have a strong influencing role on the logistics industries.

\subsubsection{Selection of policies}

First, because our research scope is the Chinese logistics industry, we only study the policies issued by state-level departments and do not consider regional factors and 
policies issued by provinces and municipalities.

Second, because we focus on the overall market value of the logistics industry, the selected policies should be able to impact all logistics companies. For policies aimed at standardizing specific industrial logistics or a single transportation mode, the number of influenced companies is small and the policies only affect a limited number of companies; thus, including these policies may introduce errors. Therefore, these types of policies were not considered in this research. For example, this study did not consider the "Opinions on Accelerating the Development of Cold Chain Logistics to Ensure Food Safety and Promoting Consumption Upgrade" issued by the General Office of the State Council (this policy is limited to cold chain logistics) and the "Circular on Publishing Action Plan for Further Structural Reform of Water Transport Supply Side (2017-2020)" issued by the MOT (this policy is limited to the water transport market), the "Guiding Opinions on Promoting the Development of the Aviation Logistics Industry" issued by the CAAC (this policy is limited to aviation logistics), etc.

Finally, this research limited the policy issue time to the period from 2013 to 2018 based on the following two reasons.

1) From a global perspective, Germany proposed the "Industry 4.0" strategy in 2013 and considered it to be part of a smart, networked world, which led to the rise of intelligent logistics (Kagermann et al., 2013). Since then, a new round of industrial transformation competition has been launched on a global scale, which has set off a wave of technological R\&D and implementation of smart factories, smart production and intelligent logistics, and it became the symbol of the fourth industrial revolution (Tjahjono et al., 2017).

2) From a Chinese perspective, the $18^{\text {th }}$ National Congress of the Communist Party of China has witnessed profound changes in Chinese policies. In the new era, new leaders have paid more attention to the promotion and application of information technology, such as the Internet, and transforming traditional industries to "wisdom +". Hence, after 2013, policies about intelligent logistics began to emerge.

During the selection process, we first focused on all 262 logistics and supply chain related policies issued by the targeted departments from 2013 to 2018 organized by CLFP ${ }^{1}$. CLFP is the first logistics and procurement industry organization in China and has been authorized to perform functions of foreign affairs, industry statistics and

\footnotetext{
${ }^{1}$ URL: http://www.chinawuliu.com.cn/special/wlycgzcfg.htm
} 
standard revisions by the government. It is also the Chinese representative of the Asia-Pacific Logistics Alliance and International Procurement Alliance and has a high authority level. The official websites of ministries and commissions were then checked to avoid missing policies. We excluded policies that only focused on certain logistics industries, which eliminated 86 policies so that 176 were retained. Meanwhile, the websites also contain a total of 21 policy interpretations and related news that do not belong to the policy category and have been removed, which means that 155 remained. Finally, according to the characteristics of intelligent logistics described above, we set up keywords as the criteria for selecting policies on intelligent logistics as shown in Table 2. In addition to the policies whose titles included the keywords, we also read all the full text of the logistics policies and set the relevant policies related to the keywords in the whole paragraph or chapter as policy samples. Panel A of Table 3 presents the method of selecting 20 intelligent logistics policies from 155 policies, and Panel B of Table 3 presents the titles and the release time of the policies, with seven from the State Council or the General Office, two from the MOC, three from the MOT, two from the NDRC, one from the SPB, one from the MOF, and four from multiple ministries.

Table 2 Intelligent logistics keywords

\begin{tabular}{l}
\hline Keywords \\
\hline Intelligent logistics, Smart logistics, Big data, blockchain, cloud \\
computing, artificial intelligence, Internet of things, Internet, information \\
platform, informatization, automation, visualization, Sharing, symbiosis \\
and connectivity
\end{tabular}


Table 3 ILP samples

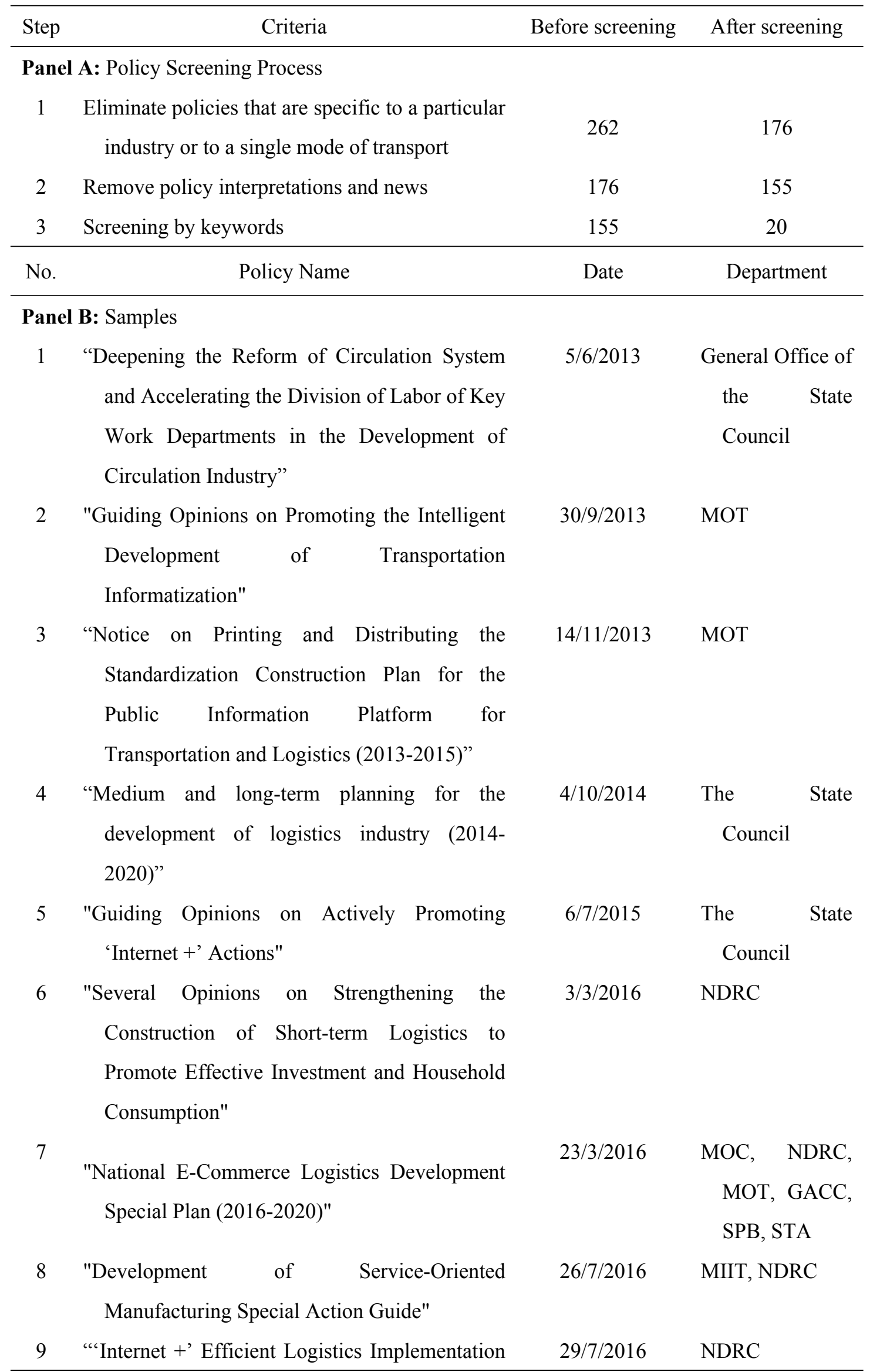


Opinions"

10 "Promoting

"Internet +" Convenient

$30 / 7 / 2016$

NDRC, MOT

Transportation to Promote the Development

of Intelligent Transportation"

11 "Promoting the Supply Side Structural Reform

11/8/2016 MOT

and Promoting the Logistics Industry to

Reduce Costs and Increase Efficiency"

12 "Notice on Forwarding the Special Action Plan

26/9/2016 General Office of

for the Reduction and Efficiency of Logistics Industry (2016-2018)"

13 "13th Five-Year Development Plan for Domestic

Trade Circulation"

14 "E-commerce 13th Five-Year Development Plan

15 "Thirteenth Five-Year Plan for the Development of Trade and Logistics"

16 "Opinions on Accelerating the Structural Reform

$18 / 5 / 2017 \quad$ SPB

of the Supply Side of the Postal Industry"

17 "Opinions on Further Promoting Logistics Cost

17/8/2017 General Office of Reduction and Efficiency Promotion to Promote the Development of the Real Economy"

18

"Guiding Opinions on Actively Promoting Supply Chain Innovation"

13/10/2017 General Office of the State Council

19 "Opinions on Promoting the Coordinated Development of E-Commerce and Express Logistics"

$23 / 1 / 2018$

General Office of the State Council

20 "Notice on Launching the Construction of 28/5/2018 MOF Modern Supply Chain System in the Circulation Sector in 2018"

\subsection{Company Samples}

\subsubsection{Sample range}

First, we selected companies listed on the China A-share market as the selection scope. Among the A-share companies, the common stock of RMB is issued by 
domestic companies for subscription and trading in the RMB by domestic institutions, organizations or individuals. It is the most mature stock market in the mainland of China and includes traditional large-scale enterprises as well as many new and hightech enterprises. There are three reasons why we selected these three stocks: first, they are the stock markets of mainland China and thus match our research scope; second, the total number of A-share listed companies is more than 3600 , which can ensure the adequacy of the sample size; finally, the data integrity of the companies is better. We collected sample companies and related data from the RESSET database ${ }^{1}$, which has good information on China. The RESSET database is widely used by Chinese scholars to study Chinese listed companies, and it contains comprehensive data and information (Wang and Qian, 2011; Li et al., 2015).

\subsubsection{Sample selection}

The development of intelligent logistics is the result of technology empowerment, innovative leading and software and hardware development (Oh and Jeong, 2019). Thus, while we study the impact of ILP on logistics service companies, we also analyze intelligent logistics equipment or system manufacturing companies. We defined these two types of companies as follows: 1) Logistics Service Companies (LSCs), which refer to service-oriented companies that provide transportation, warehousing, distribution and other logistics services; and 2) Logistics Equipment or System Manufacturing Companies (LESMCs), which refer to manufacturing enterprises that mainly produce and develop hardware for intelligent logistics equipment and technology-based companies focused on software development (Tjahjono et al., 2017). We also set up keyword databases of LSCs and LESMC to screen samples as shown in Table 4.

From October 2018 to March 2019, we searched the official introduction of the current "main business" of the all 3609 companies listed on A-share in the RESSET database. We used keywords to filter the "main business" text data one by one. If one of the keywords appeared in the "main business" text, then the corresponding company was selected as our sample company. Finally, 118 LSCs and 31 LESMCs were identified, for a total of 149 company samples. The proportion of these two types of companies is consistent with the actual situation in the industry, meaning that there are more logistics service companies. Table 5 shows the information of the company samples.

\footnotetext{
${ }^{1}$ URL: http://www.resset.cn
} 
Table 4 Keywords for the logistics companies

\begin{tabular}{lccc}
\hline Category & Keywords & $\mathrm{N}$ \\
\hline LSC & Logistics, logistics services, warehousing services, cargo transport services, 118 \\
& logistics management, supply chain, supply chain services, supply chain \\
& management & \\
LESMC & Intelligent logistics equipment, automatic logistics equipment, intelligent 31 \\
& warehouse, automatic three-dimensional warehouse, logistics robot, \\
& warehousing robot, transportation robot, intelligent transportation belt, \\
& logistics system, logistics information system, intelligent logistics \\
& accessories, logistics equipment, logistics equipment, transportation \\
& equipment, transportation equipment, storage equipment, storage equipment
\end{tabular}

Table 5 The information of the company samples

\begin{tabular}{lcc}
\hline \multicolumn{1}{c}{ Type } & Number & $\%$ of company sample \\
\hline Panel A: Company type & 118 & $79.2 \%$ \\
LSC & 31 & $20.8 \%$ \\
LESMC & 80 & $53.7 \%$ \\
State-owned company & 69 & 46.3 \\
non-State-owned company & 149 & \\
Total & Mean & Median \\
\hline & & 910.26 \\
\hline Panel B: Total assets of the company samples & 4112.75 & \\
Total assets (CNY million) & & \\
\hline
\end{tabular}

\section{Hypothesis}

In this section, we provide some empirical theories to support the development of the framework. In addition, we discuss the factors from the perspective of the government and explore the different market reactions of different enterprises in the face of ILPs from the perspective of enterprises.

\subsection{Theoretical Background and Research Framework}

Law \& finance theory was proposed by Porta et al. (1998), which holds that policies, investors, companies and financial markets are closely related. Porta et al. (1998) claimed that when investors get enough confidence from policies, they are more inclined to participate in public markets, thus encouraging the development of the markets. Based on law and finance theory, Figure 1 shows the research logic for 
this study, which is the release of an industry policy affects investors, and investors' behaviors are reflected in the stock market. In this process, the government and company factors adjust investors' behaviors.

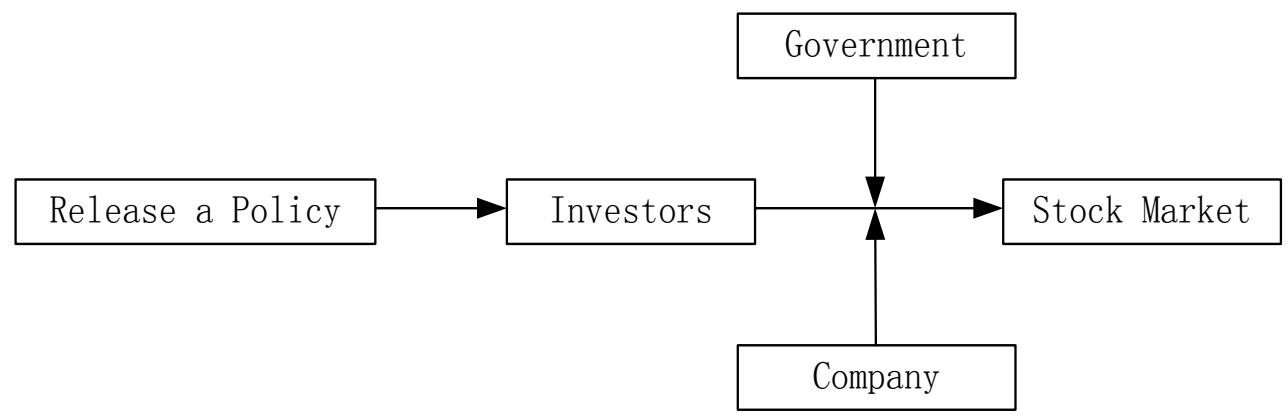

Fig. 1 Research logic for this study

Institutional Theory holds that government policy is one of the important external pressures to drive a company (Dacin et al., 2002). As a coercive pressure, policies are primary drivers for firms' decision-making (Liang et al., 2007). Government releases policies to form rules and invisible systems. We adopt Institutional Theory and discuss the government factor, such as departments function, policy content and release mode.

Resource-Based View (RBV) Theory holds that firm resources include human, capital, equipment, technology, and information resources. These resources can be divided into tangible (factory and inventory) and intangible (technology and information) (Sarkis et al., 2010). We develop the company factor hypothesis following the RBV theory. For example, the assets of logistics service companies are generally tangible, such as warehouses, vehicles and other resources to provide customers with logistics services. Logistics equipment manufacturing companies generally own more intangible assets. They provide intelligent logistics system and technology for logistics service companies. As a result, we consider the effects of ILPs on these two types of companies.

We propose the hypothesis in three aspects. Based on research logic in Figure 1, Institutional Theory and RBV Theory, Figure 2 shows the hypotheses logical architecture diagram. First, we verify whether stock market had abnormal returns for ILPs. Next, from the perspective of the government, we propose corresponding assumptions $H 2, H 3-1, H 3-2, H 3-3, H 3-4$ and $H 4$. Finally, from the perspective of companies, we explore the effects of ILPs on different companies and gave $\mathrm{H} 5 \mathrm{H}$, $H 7$ and $H 8$. 


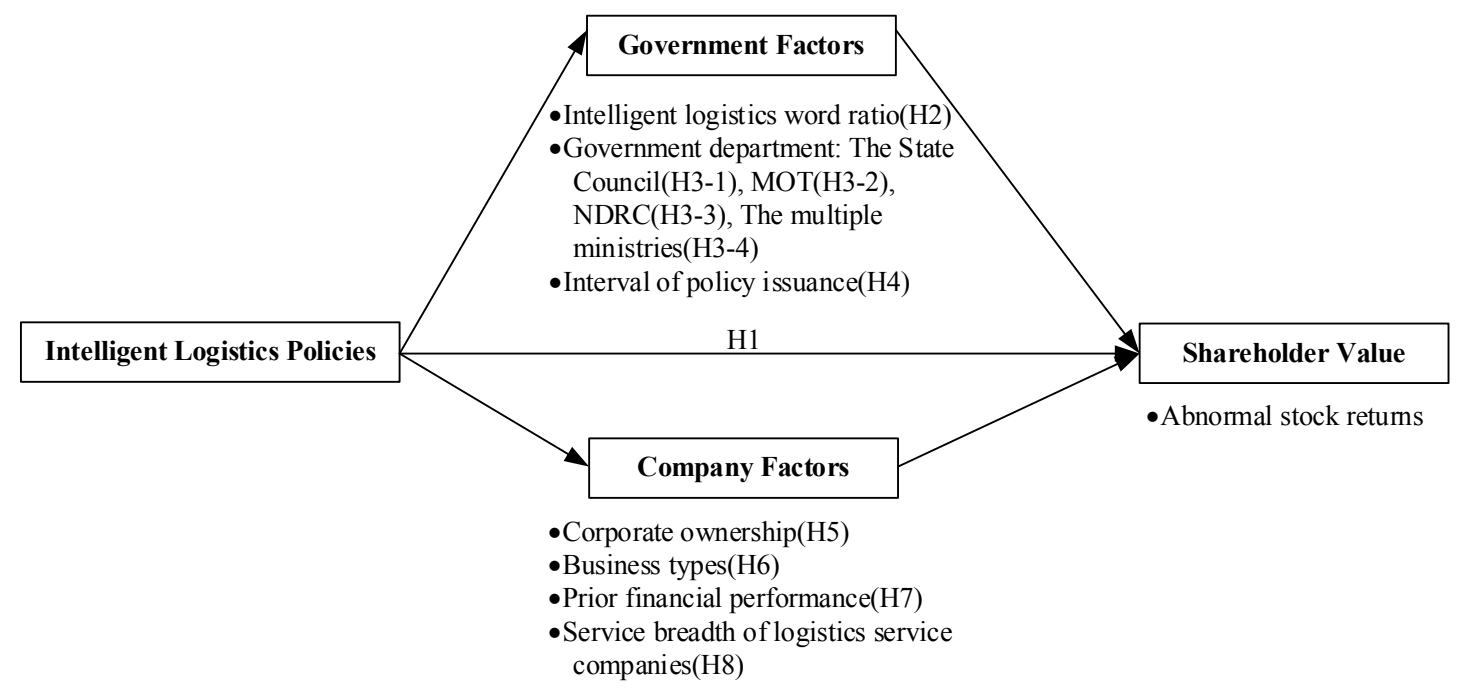

Fig. 2 The hypotheses logical architecture diagram

\subsection{ILP Release and Operating Performance}

Policy issuance is a national macro control method aimed at ensuring the rapid, coordinated and sustained development of the national economy. When the government promulgates policies to promote the development of the industry, it will promote the development of the enterprises concerned and the market will respond positively (Koussouris et al., 2015). First, if the government issue policies and sets clear development orientation for a specific industry, it is an indicator of how the government attaches importance to that industry, which also indicates positive prospects for its future development potential and improvement space (Chen et al., 2016). Second, the release of the policy is often accompanied by some supportive actions for enterprises, such as funds, land, talent and other support, which are beneficial to the future development of the enterprises. Finally, the government is an organization that ensures the stable development of society and economy (Ferro et al., 2013). Especially in China, the government has a high position in the hearts of the people; therefore, the public will follow the direction of the government when making decisions.

Law \& finance theory holds that policies, investors, companies and financial markets are closely related (Porta et al., 1998). When investors get enough confidence from policies, they are more inclined to participate in public markets, thus encouraging the development of the markets. Therefore, we propose that the ILP affects investors and investors' behaviors are reflected in the stock market. To sum up, we make the following assumption.

H1: ILP will result in a positive stock market reaction. 


\subsection{Government Factors and Market Reaction}

\subsubsection{Intelligent Logistics Word Ratio (ILWR)}

At present, the Chinese government has not issued policies specifically for intelligent logistics, although many logistics policies have mentioned intelligent logistics; therefore, developing a method of evaluating how different logistics policies focus on intelligent logistics is an important issue. Because the contents and the total word number of different policies differ, the number of intelligent logistics words in each policy is not an effective method of measuring the attention of intelligent logistics. However, the proportion of the intelligent logistics word number in the total word number represents the proportion of the government's work arrangement for intelligent logistics in the overall work. The government has made more efforts to promote intelligent logistics in a policy, which means that the government has given more support. Therefore, we used the intelligent logistics word ratio (ILWR) to evaluate how different logistics policies focus on intelligent logistics (Yang et al., 2019). We classified the policies according to the ILWR (Chen et al., 2016). Starting from the definition of intelligent logistics, we read all the policies to build a statement base according to the keyword database in Table 2. Table 6 illustrates our screening criteria. We have counted the number of words in the sentences containing key words in all 20 intelligent logistics policies. Table 7 shows the number of intelligent logistics words in each policy, the total number of words in the policy and its ILWR.

Based on Institutional Theory, government releases policies to form rules and invisible systems. The larger ILWR means the invisible system of intelligent logistics is more specific in a policy, which will convey more information to investors, so that the market will have a more positive response. In addition, since intelligent logistics has become a strategic goal of the government, a focus of enterprises and an expectation of the public (Speranza, 2018), we assume that when the policy pays more attention to intelligent logistics, that is, the larger the ILWR, the more positive the market reaction will be. Therefore, the second hypothesis is given as follows:

$H 2$ : The more ILWR in a policy, the more positive the market will react. 
Table 6 Intelligent logistics policy statement base

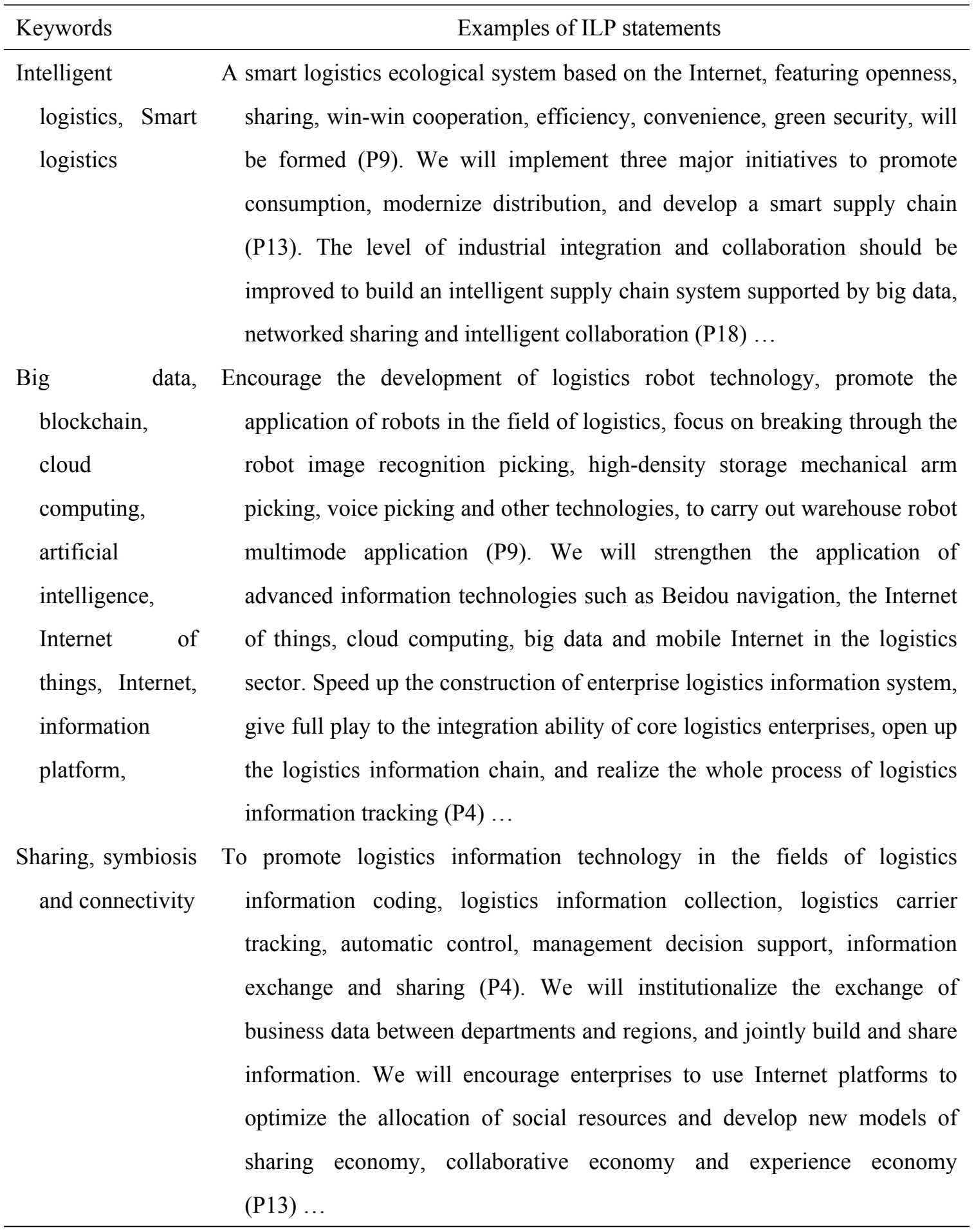


Table 7 Intelligent Logistics Word Ratio (ILWR)

\begin{tabular}{lccc}
\hline No. & $\begin{array}{c}\text { Intelligent Logistics Word } \\
\text { Number }\end{array}$ & $\begin{array}{c}\text { Total Word } \\
\text { Number }\end{array}$ & Percentage \\
\hline 1 & 609 & 5797 & $10.50 \%$ \\
2 & 1466 & 2834 & $51.73 \%$ \\
3 & 750 & 7283 & $10.31 \%$ \\
4 & 1382 & 12700 & $10.88 \%$ \\
5 & 1809 & 16682 & $10.84 \%$ \\
6 & 409 & 3104 & $13.18 \%$ \\
7 & 921 & 6704 & $13.74 \%$ \\
8 & 1353 & 8964 & $15.09 \%$ \\
9 & 2661 & 8168 & $32.58 \%$ \\
10 & 369 & 2598 & $14.20 \%$ \\
11 & 531 & 4953 & $10.72 \%$ \\
12 & 812 & 7403 & $10.97 \%$ \\
13 & 2470 & 17276 & $14.30 \%$ \\
14 & 1519 & 13066 & $11.63 \%$ \\
15 & 1427 & 9080 & $15.72 \%$ \\
16 & 655 & 6743 & $9.72 \%$ \\
17 & 856 & 5991 & $14.29 \%$ \\
18 & 643 & 5652 & $11.39 \%$ \\
19 & 388 & 3701 & $10.48 \%$ \\
20 & 501 & 4334 & $11.56 \%$ \\
\hline
\end{tabular}

\subsubsection{Government department (GD)}

The government policy is one of the important external pressures to drive a company (Dacin et al., 2002). As a coercive pressure, policies are primary drivers for firms' decision-making (Liang et al., 2007). However, Institutional Theory holds that the government has different departments, and their main responsibilities and power division are different. Therefore, we propose the effects of GDs on the market reaction are different (Liu and Zheng, 2015). Among the 262 policies from 2013 to 2018, 73 policies were issued by the MOC, 59 were issues by the State Council and the General Office, and 22 were issued by the NDRC. The total number of logistics policies issued by these three departments is much larger than that of the other departments, and the proportion is $58.8 \%$. Therefore, we focus on analyzing these 
three departments. In addition, considering that there are several ministries jointly promulgating policies, we study the following four aspects.

1) The State Council and the General Office are directly led by the Premier and the Secretary-General of the State. At the same time, they lead other ministries and commissions. Because of their greater powers, we speculate that the policies issued by them will result in the most positive stock market reaction (Sims, 1986).

2) The Ministry of Transport is the department responsible for transportation and logistics business, which is directly related to the development of the logistics industry; therefore, we speculate that the policies issued by the MOT may result in a more positive reaction among the ministries.

3) The NDRC is mainly responsible for economic development and reform and innovation; therefore, we speculate that the policy of the NDRC may also result in a more positive reaction in all ministries.

4) Four of the policy samples were issued jointly by multiple ministries. We expect that the policies issued jointly will result in a more positive stock market reaction because of the joint efforts of multiple ministries in the implementation. In summary, this research proposes the following hypotheses:

H3-1: The policies issued by the State Council and the General Office will result in the most positive stock market reaction;

H3-2: The policies issued by the MOT may result in a more positive reaction among the ministries;

H3-3: The policy of the NDRC may also result in a more positive reaction in all ministries;

H3-4: The policy issued jointly will result in a more positive stock market reaction.

\subsubsection{Interval of policy issuance (IPI)}

Government issues intelligent logistics policies without fixed time and cycle. Some policies (Policies 7, 10 and 11) were issued within 10 trading days after the last one. Interval of policy issuance may also become one of the important factors. First, we calculate the average time interval for a government department to issue logistics policies. According to section 4.3.2, the departments that issue the most relevant policies are the State Council, General Office, MOT and NDRC. In the past five years, these three departments have issued 154 policies, which exceed $58 \%$ of the total number of policies. Then, we calculate the average interval through these three departments. We found that each department publishes a logistics policy every 35 
days. We defined a policy with a release interval of less than 35 natural days as a centralized release.

Xia et al. (2016) hold that the market may exhibit the learning effect. The market cannot react positively again for similar events in a short time. A centralized release will have less surprise to the market. Therefore, the hypothesis is given as follows:

H4: The policy released centrally will result in a less positive stock market reaction.

\subsection{Company Factors and Market Reaction}

\subsubsection{Corporate ownership (CO)}

State-owned enterprise refers to the companies that are invested by the State Council and the local government that is performing the responsibilities of investors on behalf of the state. (Cull and Xu, 2003). Within the 149 company samples, there are 80 state-owned enterprises (53.7\%) and 69 non-state-owned enterprises (46.3\%), which shows that the state-owned components of logistics listed companies account for a large proportion in China.

State-owned enterprises play an important role in promoting national economic development in China (Yu et al., 2016). The board of directors of a non-state-owned enterprise can decide how to develop the company, but for state-owned enterprises, their decisions need to follow the government. The important matters (including appointments and investment) need government approval, so state-owned enterprises have closer ties with the government than other enterprises. Therefore, we expect that ILPs will have a more positive impact on the market value of state-owned enterprises compared with private enterprises.

H5: ILP has a more positive impact on the market value of state-owned enterprises.

\subsubsection{Business types (BT)}

The application of intelligent technology and equipment is essential and crucial for the development of intelligent logistics; therefore, we further study the degree of policy impact on intelligent logistics equipment or system manufacturing companies (Uckelmann, 2008).

Although intelligent technology and equipment are very important to intelligent logistics, we consider that the market reacts more positively to LSCs than to LESMCs. On the one hand, most of the specific policy formulations were aimed at optimizing the logistics service procedures, although a few mentioned logistics equipment manufacturing specifically. On the other hand, LESMCs are in the 
upstream of the supply chain as suppliers of LSCs (Cho et al., 2012). Service companies will be closer to consumers and investors (Zhou et al., 2009). We believe that investors may pay more attention to the logistics service companies. Thus H6 is proposed.

H6: The market reacts more positively to LSCs than to LESMCs.

\subsubsection{Prior financial performance (PFP)}

We discuss how prior financial performance influences the market reaction to policy. A company with a good performance has a market base and a good momentum of development. When the government gives further instructions to the company's business, investors believe that it will take advantage of the situation to achieve better development. Therefore, the market reaction to policy will be more positive for companies with good financial performance (Barber and Lyon, 1996). At the same time, companies with poor performance may not present appropriate decision-making for the current market situation and cannot respond to changes of policy quickly and reasonably (Worrell et al., 1991; Iqbal and Shetty, 1995). Therefore, the following hypothesis is proposed:

H7: The market reacts more positively to companies with good performance than to companies with poor performance.

\subsubsection{Service breadth of logistics service companies}

Logistics refers to controlling the flow of raw materials, work in process and finished products in the whole supply chain operation and providing inventory management, such as for the inventory, transportation, storage, enterprise order management, packaging and other service procedures (Donald et al., 2012). We call every basic service, such as transportation and storage, in logistics a procedure. Based on previous research (Karim, 2003; Torres et al., 2005; Liu et al., 2019), we adopted the number of service procedures to measure the service breadth and divided the sample companies into three categories: 1) a company with low service breadth $\left(\mathrm{C}_{\mathrm{L}}\right)$ refers to an enterprise that provides only one service procedure, for a total of 55 samples; 2) a company with a medium service breadth $\left(\mathrm{C}_{\mathrm{M}}\right)$ refers to an enterprise that provides multiple logistics service procedures at the same time, for a total of 31 samples; and 3$)$ a company with a high service scope $\left(\mathrm{C}_{\mathrm{H}}\right)$ refers to an enterprise that provides value-added services, such as supply chain management and financial services, while also providing all procedures, for a total of 32 samples. Intelligent logistics is performed to form a logistics ecosphere with logistics platform enterprises as the core (Speranza, 2018). $\mathrm{C}_{\mathrm{H}}$ has richer resources and can provide more service 
procedures. Driven by intelligent technology, $\mathrm{C}_{\mathrm{H}}$ is likely to transform into a platform enterprise and build a logistics ecosystem. Therefore, $\mathrm{C}_{\mathrm{H}}$ may be more important and should be more susceptible to the government's policy on intelligent logistics. The following hypothesis is proposed:

H8: The higher the service breadth of enterprises, the more positively the market reacts.

\section{Results}

\subsection{Abnormal Returns}

Because ILP may have an impact on the stock price of many logistics companies, the $R_{m t}$ of day 0 may also be affected. However, this will not change the qualitative part of our conclusion because if the stock price of all logistics companies increases under the influence of ILPs, $R_{m t}$ will be larger than that without the event, and because the estimated $\hat{\beta}_{i}$ is almost all positive, $A_{i t}$ and $\overline{A_{t}}$ will be smaller, which also reduces the test statistics. However, we still verify whether the market return $R_{m t}$ of day 0 is affected. We verify whether the market return of all companies is significantly different from the market return of the companies excluding the sample. We use the F-test and t-test to verify the relationship between their variance and mean. The results in Table 8 show that the stock price fluctuation of the sample companies does not cause abnormal fluctuations of the market average return $\left(R_{m t}\right)$. 
Table 8 Market return of day 0

\begin{tabular}{|c|c|c|c|c|}
\hline $\begin{array}{l}\text { Policy } \\
\text { number }\end{array}$ & $\begin{array}{l}\text { Mean market return } \\
\text { including the sample } \\
\text { companies } / \%\end{array}$ & $\begin{array}{l}\text { Mean market return excluding } \\
\text { the sample companies } / \%\end{array}$ & F-test & T-test \\
\hline 1 & -1.603 & -1.621 & 0.179 & -0.307 \\
\hline 2 & 1.628 & 1.608 & 0.004 & 0.291 \\
\hline 3 & 1.968 & 1.965 & 0.024 & 0.052 \\
\hline 4 & 1.507 & 1.500 & 0.000036 & 0.113 \\
\hline 5 & -8.932 & -8.977 & 0.538 & 0.401 \\
\hline 6 & -3.370 & -3.374 & 0.062 & 0.414 \\
\hline 7 & -1.567 & -1.570 & 0.078 & 0.032 \\
\hline 8 & -4.795 & -4.867 & 0.287 & 0.799 \\
\hline 9 & -1.711 & -1.741 & 0.003 & 0.419 \\
\hline 10 & -0.505 & -0.503 & 0.001 & -0.023 \\
\hline 11 & -1.538 & -1.536 & 0.000172 & 0.327 \\
\hline 12 & -2.355 & -2.358 & 0.036 & 0.043 \\
\hline 13 & 0.040 & 0.017 & 0.004 & 0.383 \\
\hline 14 & 0.150 & 0.153 & 0.133 & -0.077 \\
\hline 15 & -0.131 & -0.167 & 0.044 & 0.619 \\
\hline 16 & -0.597 & -0.599 & 0.092 & 0.020 \\
\hline 17 & -0.335 & -0.363 & 0.104 & 0.583 \\
\hline 18 & -1.908 & -1.922 & 0.098 & 0.222 \\
\hline 19 & 0.228 & 0.213 & 0.001 & 0.307 \\
\hline 20 & -0.793 & -0.809 & 0.009 & -0.273 \\
\hline
\end{tabular}

We calculate the abnormal return of 149 sample companies on day 0 and conduct the clustered version of the t-test to analyze its significance according to Brown (1985) and Hendricks et al. (2019). Finally, 20 test results are shown in Panel A of Table 9. Because some stock data were missing on the event day, we exclude those companies in the analysis, and $\mathrm{N}$ is the validation sample size on the event day. The mean and median abnormal returns of 11 policies (Policy 1, 2, 3, 6, 8, 9, 13, 15, 17, 18 , and 20) are both significantly greater than zero at the $1 \%-10 \%$ level. In addition, the positive percentage of the accumulated abnormal returns is not significantly greater than $50 \%$. Three reasons are found for the policies that have no significant reaction: 1) four of these policies (Policy 4, 5, 14, and 16) are due to previous 
briefings or related news releases ranging from one week to one month in advance, and our calculations show that the market also reacts positively when the policy is disclosed in advance; 2) three of these policies (Policies 7, 10 and 11) are issued within 10 trading days after the last one, and the results show that the market cannot react positively again in a short time; thus, we analyze policies issued in a short period of time in section 5.3.2; and 3) although the average abnormal return of two policies (Policy 12 and 19) is significantly greater than zero at the level of $10 \%$, the median and positive percentage are not significant, which indicates there are some unknown factors in the market and some extreme values affect the test results. In summary, because the special situation of nine policies (Policy 4, 5, 7, 10, 11, 12, 14, 16, and 19) is not within our research scope, we exclude them and only consider the other 11 policies in the subsequent analysis. We analyze the results of the 11 policies together to obtain the average level. Panel B of Table 9 shows that the mean and median abnormal returns of day 0 are $0.625 \%$ and $0.352 \%$, which are significantly greater than zero at the $1 \%$ level. The positive percentage is $63 \%$, which is significantly greater than $50 \%$. 
Table 9 Event period abnormal returns under the ILPs

\begin{tabular}{|c|c|c|c|c|c|c|c|}
\hline No. & $\mathrm{N}$ & $\begin{array}{c}\text { Mean } \\
\text { abnormal } \\
\text { return/\% }\end{array}$ & t-statistic & $\begin{array}{l}\text { Median } \\
\text { abnormal } \\
\text { return/\% }\end{array}$ & $\begin{array}{l}\text { Wilcoxon } \\
\text { signed-rank } \\
\text { Z-statistic }\end{array}$ & $\begin{array}{l}\text { Abnormal } \\
\text { returns } \\
\text { positive/\% }\end{array}$ & $\begin{array}{l}\text { Binomial } \\
\text { sign test } \\
\text { Z-statistic }\end{array}$ \\
\hline \multicolumn{8}{|c|}{ Panel A: Event Period Abnormal Returns for Every Policy } \\
\hline 1 & 107 & 0.39 & $1.400 *$ & 0.304 & $2.999 * * *$ & 65 & $3.094 * * *$ \\
\hline 2 & 107 & 0.86 & $3.080 * * *$ & 0.406 & $2.956 * * *$ & 64 & $2.707 * * *$ \\
\hline 3 & 101 & 0.61 & $2.365 * * *$ & 0.056 & $2.723 * * *$ & 59 & $1.700^{*}$ \\
\hline 4 & 99 & 0.33 & 1.031 & -0.14 & -0.129 & 46 & 0.603 \\
\hline 5 & 97 & 0.25 & 0.781 & -0.4 & -0.754 & 43 & 1.218 \\
\hline 6 & 107 & 0.76 & $1.467^{*}$ & 0.537 & $2.138 * *$ & 59 & $1.740 *$ \\
\hline 7 & 111 & 0.31 & 0.969 & -0.2 & -0.494 & 41 & 1.898 \\
\hline 8 & 113 & 1.03 & $2.751 * * *$ & 0.862 & $3.691 * * *$ & 67 & $3.575^{* * *}$ \\
\hline 9 & 115 & 0.52 & $1.379 *$ & 0.284 & $1.934^{* *}$ & 58 & $1.679^{*}$ \\
\hline 10 & 117 & -0.04 & -0.125 & 0.1 & 0.330 & 53 & -0.555 \\
\hline 11 & 111 & 0.23 & 0.606 & 0.232 & $2.115^{* *}$ & 59 & $1.708^{*}$ \\
\hline 12 & 111 & 0.28 & 0.823 & 0.374 & $2.587 * * *$ & 60 & $2.002 * *$ \\
\hline 13 & 114 & 0.72 & $2.396 * * *$ & 0.216 & $3.609 * * *$ & 66 & $3.278 * * *$ \\
\hline 14 & 120 & -0.07 & -0.219 & 0 & -0.431 & 48 & 0.269 \\
\hline 15 & 121 & 0.65 & $2.332 * *$ & 0.469 & $4.034 * * *$ & 67 & $3.636^{* * *}$ \\
\hline 16 & 120 & 0.17 & 0.531 & -0.1 & -0.079 & 43 & 1.514 \\
\hline 17 & 118 & 0.56 & $1.454^{*}$ & 0.412 & $3.084 * * *$ & 66 & $3.406^{* * *}$ \\
\hline 18 & 117 & 0.47 & $1.346^{*}$ & 0.214 & $2.933 * * *$ & 58 & $1.664^{*}$ \\
\hline 19 & 112 & 0.30 & 0.741 & -0.065 & 0.581 & 47 & 0.472 \\
\hline 20 & 128 & 0.39 & $1.378 *$ & 0.505 & $3.515^{* * *}$ & 66 & $3.624 * * *$ \\
\hline \multicolumn{2}{|c|}{$\mathrm{N}$} & $\begin{array}{c}\text { Mean } \\
\text { abnormal } \\
\text { return/\% }\end{array}$ & t-statistic & $\begin{array}{l}\text { Median } \\
\text { abnormal } \\
\text { return/\% }\end{array}$ & $\begin{array}{l}\text { Wilcoxon } \\
\text { signed-rank } \\
\text { Z-statistic }\end{array}$ & $\begin{array}{l}\text { Abnormal } \\
\text { returns } \\
\text { positive/\% }\end{array}$ & $\begin{array}{l}\text { Binomial } \\
\text { sign test } \\
\text { Z-statistic }\end{array}$ \\
\hline
\end{tabular}

Panel B: Event Period Abnormal Returns for 11 Effective Policies

\begin{tabular}{lllllll}
1248 & 0.625 & $9.253 * * *$ & 0.352 & $10.123 * * *$ & 63 & $9.370 * * *$ \\
\hline
\end{tabular}

All tests are one-tailed: $* \mathrm{p}<=0.10, * * \mathrm{p}<=0.05, * * * \mathrm{p}<=0.01$

Part 4.3.1 shows that most of the 11 policies contain $10 \%$ to $20 \%$ of the content of intelligent logistics, which is a relatively low number. To illustrate whether the intelligent logistics sector makes the market react more positively or not, we conduct 
a control test on every policy sample. Table 10 shows the control policies (non-ILPs) that have a similar theme, the same publishing department and a publishing time that does not exceed one year from the sample policies. Because the themes of Policy 2 ("Guiding Opinions on Promoting the Intelligent Development of Transportation Informatization") and Policy 9 (“"Internet + ' Efficient Logistics Implementation Opinions") are intelligent logistics, none of the policies are similar to their themes but do not include intelligent logistics. Thus, they are excluded in the control test.

Table 11 shows the clustered version of the t-tests of 9 control policies on day 0 , which indicates only two policies have a significant impact on the market while most of them have not. The nine ILPs and corresponding control policies were tested by the one-sample T-test, nonparametric test and independent sample T-test to compare their differences. Table 12 shows that the mean abnormal return caused by the ILP is $0.613 \%$, which is significantly greater than zero at the $1 \%$ level. The statistical data of the non-ILPs are not significant. In addition, through independent sample T-test, we conclude that the impact of ILPs on the market is significantly greater than that of non-ILPs; therefore, we can explain the part of the intelligent logistics policies that produces a market reaction or because it makes the market reaction more positive. Therefore, $H 1$ is accepted. 


\begin{tabular}{|c|c|c|c|c|c|c|c|c|c|}
\hline \multicolumn{5}{|c|}{ ILP } & \multicolumn{5}{|c|}{ Control Policy (non-ILP) } \\
\hline No. & Name & Date & Department & Number & No. & Name & Date & Department & Number \\
\hline \multirow[t]{5}{*}{1} & "Deepening the Reform of Circulation & $5 / 6 / 2013$ & General & 5797 & $1 \mathrm{a}$ & "Notice on the & $15 / 1 / 2013$ & General & 2588 \\
\hline & System and Accelerating the & & Office of & & & Comprehensive Work Plan & & Office of & \\
\hline & Division of Labor of Key Work & & the State & & & for Reducing Circulation & & the State & \\
\hline & Departments in the Development of & & Council & & & Expenses and Improving & & Council & \\
\hline & Circulation Industry" & & & & & Circulation Efficiency" & & & \\
\hline \multirow[t]{5}{*}{3} & "Notice on Printing and Distributing & $14 / 11 / 2013$ & MOT & 7283 & $3 a$ & "Opinions on Strengthening & $17 / 9 / 2013$ & MOT & 2683 \\
\hline & the Standardization Construction & & & & & the Standardization of & & & \\
\hline & Plan for the Public Information & & & & & Transportation" & & & \\
\hline & Platform for Transportation and & & & & & & & & \\
\hline & Logistics (2013-2015)" & & & & & & & & \\
\hline \multirow[t]{6}{*}{6} & "Several Opinions on Strengthening & $3 / 3 / 2016$ & NDRC & 3104 & $6 \mathrm{a}$ & "Guidance on promoting the & $2 / 3 / 2017$ & NDRC & 4274 \\
\hline & the Construction of Short-term & & & & & improvement of logistics & & & \\
\hline & Logistics to Promote Effective & & & & & service quality, speeding & & & \\
\hline & Investment and Household & & & & & up the development of & & & \\
\hline & Consumption" & & & & & service-oriented & & & \\
\hline & & & & & & manufacturing" & & & \\
\hline \multirow[t]{3}{*}{8} & "Development of Service-Oriented & $26 / 7 / 2016$ & MIIT, & 8964 & $8 \mathrm{a}$ & "Accelerate the development & $25 / 5 / 2015$ & MIIT & 5071 \\
\hline & Manufacturing Special Action & & NDRC & & & of service-oriented & & & \\
\hline & Guide" & & & & & manufacturing" & & & \\
\hline \multirow[t]{4}{*}{13} & "13th Five-Year Development Plan & $11 / 11 / 2016$ & MOC & 17276 & $13 \mathrm{a}$ & "13th Five-Year Plan for & $22 / 12 / 2016$ & MOC & 10738 \\
\hline & for Domestic Trade Circulation" & & & & & Domestic & & & \\
\hline & & & & & & Circulation & & & \\
\hline & & & & & & Standardization & & & \\
\hline
\end{tabular}




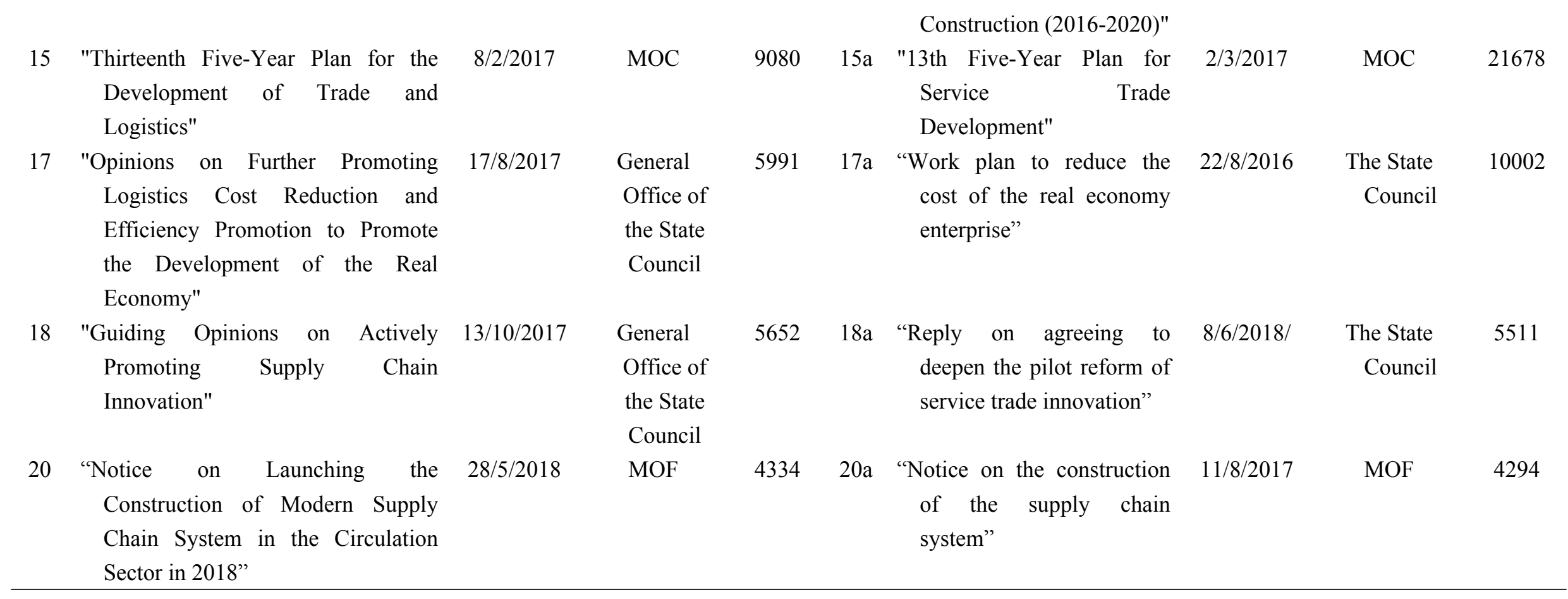

Note: The left side of each column in the table shows the ILPs studied in this paper (Policy 1, 3, 6, 8, 13, 15, 17, 18, 20, with the same policy number as in Table 3), and the right side is the control policies (non-ILPs 1a, 3a, 6a, 8a, 13a, 15a, 17a, 18a, 20a) that we have selected without intelligent logistics content. The table shows their policy name, publisher, release date and total words, which can be used to test the role of intelligent logistics content in the sample. 
Table 11 Event period abnormal returns under the control policies

\begin{tabular}{cccccccc}
\hline No. & $\mathrm{N}$ & $\begin{array}{c}\text { Mean } \\
\text { abnormal } \\
\text { return/\% }\end{array}$ & t-test & $\begin{array}{c}\text { Median } \\
\text { abnormal } \\
\text { return/\% }\end{array}$ & $\begin{array}{c}\text { Wilcoxon } \\
\text { signed-rank } \\
\text { Z-statistic }\end{array}$ & $\begin{array}{c}\text { Abnormal } \\
\text { returns } \\
\text { positive/\% }\end{array}$ & $\begin{array}{c}\text { Binomial sign } \\
\text { test Z-statistic }\end{array}$ \\
\hline $1 \mathrm{a}$ & 108 & -0.11 & -0.396 & -0.24 & $2.569^{* * *}$ & 36 & $-2.791^{* * *}$ \\
3a & 121 & -0.07 & -0.252 & 0.288 & $1.684^{*}$ & 40 & $-2.000^{* *}$ \\
$6 \mathrm{a}$ & 132 & 0.45 & $1.607^{*}$ & 0.254 & $3.576^{* * *}$ & 66 & $3.642^{* * *}$ \\
$8 \mathrm{a}$ & 107 & 0.42 & 1.220 & 0.592 & 1.383 & 55 & 0.967 \\
$13 \mathrm{a}$ & 125 & 0.14 & 0.467 & 0.071 & 0.538 & 51 & 0.179 \\
$15 \mathrm{a}$ & 122 & -0.38 & $-1.355^{*}$ & -0.27 & $-2.827^{* * *}$ & 37 & $-2.705^{* * *}$ \\
$17 \mathrm{a}$ & 126 & -0.10 & -0.267 & -0.14 & -1.411 & 43 & -1.514 \\
$18 \mathrm{a}$ & 141 & -0.05 & -0.148 & -0.06 & -0.536 & 48 & -0.337 \\
$20 \mathrm{a}$ & 130 & -0.17 & -0.439 & -0.02 & -0.594 & 48 & -0.263 \\
\hline
\end{tabular}

All tests are one-tailed: ${ }^{*} \mathrm{p}<=0.10,{ }^{* *} \mathrm{p}<=0.05,{ }^{* * *} \mathrm{p}<=0.01$

Table 12 ILPs and non-ILPs

\begin{tabular}{lcc}
\hline & ILPs & non-ILPs \\
\hline $\mathrm{N}$ & 1026 & 1492 \\
Mean abnormal return/\% & 0.613 & 0.024 \\
$\mathrm{t}-$ test & $8.423^{* * *}$ & 0.434 \\
Median abnormal return/\% & 0.37 & 0.08 \\
Wilcoxon signed-rank Z- & $9.582^{* * *}$ & -1.233 \\
statistic & & \\
Abnormal returns positive/\% & 64 & 48 \\
Binomial sign test Z-statistic & $8.835^{* * *}$ & -1.269 \\
\hline
\end{tabular}

\begin{tabular}{ll}
\hline Independent sample T test $6.481^{* * *}$ \\
\hline
\end{tabular}

All tests are one-tailed: ${ }^{*} \mathrm{p}<=0.10,{ }^{*} \mathrm{p}<=0.05,{ }^{* * *} \mathrm{p}<=0.01$

\subsection{Cross-sectional Regression Analysis}

We examine the multiple hypotheses in the fourth section. We use multiple regression estimates to test how independent variables express the hypotheses. The dependent variable is the average abnormal return of the sample company on day 0 . The independent variable includes the variable and the control variable corresponding to the hypothesis.

5.2.1 Independent variable 
Intelligent Logistics Words Ratio (ILWR): Considering that the ILWR values of some policies are too large and discontinuous (Policy 9 is $32.58 \%$, Policy 2 is $51.73 \%$, and other policies are approximately 10\%), we use the median ILWR value to distinguish between high and low ILWR, with values higher than the median given a value of 1 and the remaining values given a value of 0 . Referring to hypothesis 2 , the coefficient of the variable should be positive.

Government Department $(G D)$ : There are different government departments in the sample. The samples are classified as follows: 1) If the policies are issued by the State Council and the General Office, the variable is 1 and named THE STATE COUNCIL; otherwise, it is 0 . Referring to hypothesis $3-1$, the variable coefficient should be positive. 2) If the policies are issued by the MOT, the variable is 1 and named MOT; otherwise, it is 0 . Referring to hypothesis 3-2, the variable coefficient should be positive. 3) If the policies are issued by the NDRC, the variable is 1 and named $N D R C$; otherwise, it is 0 . Referring to hypothesis 3-3, the variable coefficient should be positive. 4) If the policies are issued by two or more departments, the variable is 1 and named THE MULTIPLE MINISTRIES; otherwise, it is 0. Referring to hypothesis $3-4$, the variable coefficient should be positive. To avoid the influence of the same type of variables, we don't use the four variables (THE STATE COUNCIL, MOT, NDRC, THE MULTIPLE MINISTRIES) in the basic model but analyze them one by one in 5.3.1 as a model extension.

Interval of policy issuance (IPI): Referring to hypothesis 4, we defined IPI according to the following rules: We defined a policy with a release interval of less than 35 natural days as a centralized release, and if other intelligent logistics policies are issued within the first 35 natural days of the policy release, the IPI is 0; otherwise, it is 1 . There are four centralized policies (policies 7, 9, 10, and 11). We don't discuss the policies which have not affected the market in the basic model. IPI is not discussed in the basic model, but is analyzed in section 5.3.2. Through a preliminary observation, we find that a centralized release will not be conducive to the market reaction; therefore, the expectation is positive.

Corporate Ownership $(C O)$ : The main types of company are state-owned, private, joint venture, etc. This paper mainly study the difference between stateowned enterprises and other non-state-owned enterprises. Therefore, $C O$ is 1 if the company is state-owned; otherwise, it is 0 . Referring to hypothesis 5 , the coefficient of the variable should be positive.

Business Type $(B T)$ : We have defined the logistics service company and the 
logistics equipment or system manufacturing company. If the company is a LESMC, then the $B T$ is 1 . If it is an LSC, then the $B T$ is 0 . Referring to hypothesis 6 , the coefficient of the variable is negative.

Prior Financial Performance ( $P F P)$ : We used the company's total return on assets (ROA) in the last quarter before the policy announcement to represent the company's prior financial performance (Jacobs and Singhal, 2014). Referring to hypothesis 7 , the variable coefficient should be positive.

\subsubsection{Control variable}

We introduce several control variables based on policy and company aspects to evaluate the stability of our hypothesis test. On one hand, we consider whether the market pays attention to a policy in time, which depends on whether the policy will provide some financial support to the industry. Because financial support is the most direct driving factor for the development of the company. Financial support (FST) is set to 1 if the policy provides financial support and the criteria are as follows: 1) The policy from the MOF. 2) Policies issued by other departments and supported by the MOF. That means the policy contains the content that there is financial support and the MOF is responsible for the implementation of the policy, such as Policy 1: "Central and local funds should actively support the construction of qualified multimodal transport facilities, urban and rural distribution network, cold chain logistics of agricultural products, logistics standardization and information technology and other logistics projects through existing channels; therefore, as to give full play to the exemplary role of government investment (Ministry of Finance is in charge)."

On the other hand, we consider the firm size $(F S)$ that will impact the market reaction. We used the natural logarithm of the company's total assets in the quarter prior to the policy release to represent the size of the company (Shams and Gunasekarage, 2016).

\subsubsection{Basic regression model}

We first analyze the following basic regression models to test the hypotheses.

$$
A_{i 0}=\beta_{0}+\beta_{1} I L W R+\beta_{2} B T+\beta_{3} C O+\beta_{4} P F P+\beta_{5} F S T+\beta_{6} F S+\varepsilon_{i}
$$

where $A_{i 0}$ is the day 0 abnormal return from the Market model, $\varepsilon_{i}$ is the error term, and the other variables are as defined above. Table 13 presents the parameter estimates ( $t$-values in parentheses) for the regression model in Equation (8). As predicted, the $I L W R$ is positive and statistically significant at the $1 \%$ level. Thus, when the ILWR is high, the market reaction will be more positive. At the same time, 
we conduct a one-sample T-test to test whether the market reactions of two kinds of samples are significantly positive and independent sample T-test to test whether they are significantly different. The results shown in Table 14 support our hypothesis; therefore, we accept $H 2$.

Meanwhile, $C O$ is positive and statistically significant at the $1 \%$ level, which shows that state-owned firms experienced more positive abnormal returns compared to non-state-owned firms. The one-sample T-test and independent sample T-test results shown in Table 15 also support our hypothesis; therefore, we accept H5.

Given the theoretical and empirical literature that we outline in the development of $H 6$ and $H 7$, the lack of a significant association among the abnormal returns, PFP, and $B T$ is surprising. To explore this issue further, we examine whether the market reaction to the BT is moderated by the firm's prior financial performance. To test this, we perform a model expansion in 5.3.3.

Table 13 Parameter estimates (t-statistics) from basic regression results

\begin{tabular}{|c|c|c|c|c|c|}
\hline Adjusted $\mathrm{R}^{2}$ & & Durbin-Watso & value & F-value & $\mathrm{N}$ \\
\hline \multicolumn{6}{|l|}{ Panel A: Model } \\
\hline \multirow[t]{2}{*}{$3.5 \%$} & & 1.720 & & $7.507 * * *$ & 1238 \\
\hline & Variable & Expectation & Parameter & T-value & VIF \\
\hline \multicolumn{6}{|l|}{ Panel B: Parameter Estimates } \\
\hline Intercept & $\beta_{0}$ & & -0.0113 & -0.988 & \\
\hline Intelligent Logistics Word Ratio & $I L W R$ & + & 0.0025 & $1.683^{* *}$ & 1.143 \\
\hline Business Type & $B T$ & - & -0.0003 & -0.135 & 1.283 \\
\hline Corporate Ownership & $\mathrm{CO}$ & + & 0.0076 & $4.522 * * *$ & 1.501 \\
\hline Prior Financial Performance & $P F P$ & + & -0.0147 & -0.765 & 1.019 \\
\hline Financial Support & $F S T$ & & -0.0008 & -0.576 & 1.134 \\
\hline Firm Size & $F S$ & & 0.0005 & 1.042 & 1.365 \\
\hline
\end{tabular}

All tests are one-tailed: ${ }^{*} \mathrm{p}<=0.10,{ }^{*} \mathrm{p}<=0.05,{ }^{* *} \mathrm{p}<=0.01$. 
Table 14 T-test for ILWR

\begin{tabular}{|c|c|c|c|c|c|c|c|c|}
\hline Category & $\mathrm{N}$ & $\begin{array}{c}\text { Mean } \\
\text { abnormal } \\
\text { return/\% }\end{array}$ & t-statistic & $\begin{array}{l}\text { Median } \\
\text { abnormal } \\
\text { return/\% }\end{array}$ & $\begin{array}{l}\text { Wilcoxon } \\
\text { signed- } \\
\text { rank Z- } \\
\text { statistic }\end{array}$ & $\begin{array}{l}\text { Abnormal } \\
\text { returns } \\
\text { positive/\% }\end{array}$ & $\begin{array}{l}\text { Binomial } \\
\text { sign test } \\
\text { Z- } \\
\text { statistic }\end{array}$ & $\begin{array}{l}\text { Independent } \\
\text { sample T- } \\
\text { test }\end{array}$ \\
\hline High & 795 & 0.72 & $7.827 * * *$ & 0.4 & $8.094^{* * *}$ & 64 & $7.803 * * *$ & \\
\hline $\begin{array}{c}\text { ILWR } \\
\text { Low }\end{array}$ & 453 & 0.45 & $4.990 * * *$ & 0.3 & $6.118 * * *$ & 62 & $5.168 * * *$ & $1.968 * *$ \\
\hline ILWR & & & & & & & & \\
\hline
\end{tabular}

All tests are one-tailed: ${ }^{*} \mathrm{p}<=0.10, * * \mathrm{p}<=0.05, * * * \mathrm{p}<=0.01$.

Table 15 T-test for CO

\begin{tabular}{|c|c|c|c|c|c|c|c|c|}
\hline Category & $\mathrm{N}$ & $\begin{array}{c}\text { Mean } \\
\text { abnormal } \\
\text { return/\% }\end{array}$ & t-statistic & $\begin{array}{l}\text { Median } \\
\text { abnormal } \\
\text { return/\% }\end{array}$ & $\begin{array}{l}\text { Wilcoxon } \\
\text { signed- } \\
\text { rank Z- } \\
\text { statistic }\end{array}$ & $\begin{array}{l}\text { Abnormal } \\
\text { returns } \\
\text { positive/\% }\end{array}$ & $\begin{array}{l}\text { Binomial } \\
\text { sign test } \\
\text { Z-statistic }\end{array}$ & $\begin{array}{l}\text { Independent } \\
\text { sample T- } \\
\text { test }\end{array}$ \\
\hline State- & 771 & 0.95 & $12.179 * * *$ & 0.5 & $12.672 * * *$ & 70 & $11.308^{* * *}$ & \\
\hline owned & & & & & & & & $6.265 * * *$ \\
\hline $\begin{array}{l}\text { non-State- } \\
\text { owned }\end{array}$ & 477 & 0.10 & 0.847 & 0.1 & 0.691 & 52 & 0.733 & \\
\hline
\end{tabular}

All tests are one-tailed: ${ }^{*} \mathrm{p}<=0.10,{ }^{*} \mathrm{p}<=0.05,{ }^{* * *} \mathrm{p}<=0.01$.

\subsection{Model Expansion}

\subsubsection{Government department}

We estimate the following regression model to test $H 3$ :

$$
\begin{aligned}
A_{i 0}= & \beta_{0}+\beta_{1} I L W R+\beta_{2} B T+\beta_{3} C O+\beta_{4} P F P \\
& +\beta_{5} F S T+\beta_{6} F S+\beta_{7} G D+\varepsilon_{i}
\end{aligned}
$$

where $A_{i 0}$ is the day 0 abnormal return from the Market model; $G D$ is the government department, which includes THE STATE COUNCIL, MOT, NDRC and THE MULTIPLE MINISTRIES; $\varepsilon_{i}$ is the error term; and the other variables are as defined above.

To avoid the influence of the same type of variables, four factors (THE STATE COUNCIL, MOT, NDRC, THE MULTIPLE MINISTRIES) of GD are added to the 
regression equation one by one (Tambe, 2014) and the regression analyses are carried out separately. Table 16 shows that THE STATE COUNCIL and MOT are insignificant and NDRC and THE MULTIPLE MINISTRIES are positive and statistically significant at the $10 \%$ and $5 \%$ level, respectively. Therefore, we reject H3-1 and H3-2 and accept H3-3 and H3-4. The policy influence of the State Council and the General Office, which are the leading bodies, is not the highest and inferior to that of the NDRC. The market will react more positively when multiple ministries jointly issue policies. In addition, we observe that the $I L W R$ and $C O$ are still significant in different regression equations, which can prove the robustness of the model. H3-3 enriches institutional theory. It's commonly known that the functions of government departments are different and departments with higher power have greater influence on social economy (Kong, 2019). H3-3 shows that institutional theory has particularity in the economy. The ministries with less power but closer responsibilities may have more influence in certain industries. 
Table 16 Parameter estimates (t-statistics) from GD regression results

\begin{tabular}{|c|c|c|c|c|}
\hline & (1) & (2) & (3) & (4) \\
\hline & THE STATE & MOT & NDRC & THE \\
\hline & COUNCIL & & & MULTIPLE \\
\hline & & & & MINISTRIES \\
\hline \multirow[t]{2}{*}{ Intercept } & -0.965 & -1.049 & -1.081 & -1.109 \\
\hline & $(-0.0111)$ & $(-0.0123)$ & $(-0.0125)$ & $(-0.0127)$ \\
\hline \multirow[t]{2}{*}{$I L W R$} & $1.555^{*}$ & $1.713 * *$ & $1.635^{* *}$ & $1.791 * *$ \\
\hline & $(0.0024)$ & $(0.0027)$ & $(0.0026)$ & $(0.0029)$ \\
\hline \multirow[t]{2}{*}{$B T$} & -0.130 & -0.121 & -0.129 & -0.127 \\
\hline & $(-0.0003)$ & $(-0.0002)$ & $(-0.0002)$ & $(-0.0002)$ \\
\hline \multirow[t]{2}{*}{$\mathrm{CO}$} & $4.526^{* * *}$ & $4.479 * * *$ & $4.510 * * *$ & $4.558 * * *$ \\
\hline & $(0.0076)$ & $(0.0076)$ & $(0.0076)$ & $(0.0077)$ \\
\hline \multirow[t]{2}{*}{$P F P$} & -0.765 & -0.792 & -0.770 & -0.784 \\
\hline & $(-0.0147)$ & $(-0.0153)$ & $(-0.0148)$ & $(-0.0150)$ \\
\hline \multirow[t]{2}{*}{$F S T$} & -0.3364 & -0.246 & -0.258 & -0.297 \\
\hline & $(-0.0006)$ & $(-0.0004)$ & $(-0.0004)$ & $(-0.0005)$ \\
\hline \multirow[t]{2}{*}{$F S$} & 1.029 & 1.080 & 1.039 & 1.045 \\
\hline & $(0.0005)$ & $(0.0006)$ & $(0.0005)$ & $(0.0005)$ \\
\hline \multirow[t]{2}{*}{ THE STATE COUNCIL } & -0.3418 & & & \\
\hline & $(-0.0006)$ & & & \\
\hline \multirow[t]{2}{*}{$M O T$} & & 0.394 & & \\
\hline & & $(0.0009)$ & & \\
\hline \multirow[t]{2}{*}{$N D R C$} & & & $1.564 *$ & \\
\hline & & & $(0.0005)$ & \\
\hline MULTIPLE & & & & $2.110 * *$ \\
\hline MINISTRIES & & & & $(0.0024)$ \\
\hline Observations & 1248 & 1248 & 1248 & 1248 \\
\hline $\mathrm{R}^{2}$ & $3.5 \%$ & $3.5 \%$ & $3.5 \%$ & $3.5 \%$ \\
\hline $\mathrm{D}-\mathrm{W}$ & 1.720 & 1.720 & 1.720 & 1.720 \\
\hline $\mathrm{F}$ & $6.447 * * *$ & $6.452 * * *$ & $6.449 * * *$ & $6.482 * * *$ \\
\hline
\end{tabular}

All tests are one-tailed: ${ }^{*} \mathrm{p}<=0.10, * * \mathrm{p}<=0.05, * * * \mathrm{p}<=0.01$.

5.3.2 Interval of policy issuance

In this section, to prevent the omission of the sample, certain policies (No. 7, 10, 
11) are temporarily excluded because the issue of the time interval should be included at the same time to ensure that the demonstration is more comprehensive. Therefore, based on the 11 policies above (Policy 1, 2, 3, 6, 8, 9, 13, 15, 17, 18, and 20), we add Policy 7, 10, and 11 into the model.

We estimate the following regression model:

$$
\begin{aligned}
A_{i 0}= & \beta_{0}+\beta_{1} I L W R+\beta_{2} B T+\beta_{3} C O+\beta_{4} P F P \\
& +\beta_{5} F S T+\beta_{6} F S+\beta_{7} I P I+\varepsilon_{i}
\end{aligned}
$$

Table 17 indicates that $I P I$ is positive and statistically significant at the $1 \%$ level, which proves that a centralized release is not conducive to a positive market reaction and will reduce the effect of policy implementation. We accept $H 4$. Thus, a valuable suggestion to the government would be to focus additional efforts on the quality of the policy rather than the quantity. At the same time, ILWR and $C O$ are still significant, which once again confirmed the robustness of the previous conclusions.

\begin{tabular}{|c|c|c|c|c|}
\hline $\mathrm{R}^{2}$ & Adjusted $\mathrm{R}^{2}$ & Durbin-Watson value & F-value & $\mathrm{N}$ \\
\hline \multicolumn{5}{|c|}{ Panel A: Model } \\
\hline 0.062 & 0.058 & 1.685 & $14.848 * * *$ & 1578 \\
\hline Variable & expectation & Parameter & T-value & VIF \\
\hline \multicolumn{5}{|c|}{ Panel B: Parameter Estimates } \\
\hline$\beta 0$ & & -0.0072 & -0.715 & \\
\hline$I L W R$ & + & 0.0034 & $2.580 * * *$ & 1.277 \\
\hline$B T$ & - & -0.0015 & -0.858 & 1.283 \\
\hline$C O$ & + & 0.0058 & $3.972 * * *$ & 1.498 \\
\hline$P F P$ & + & -0.0145 & -0.970 & 1.018 \\
\hline$F S T$ & & -0.0040 & $-3.150 * * *$ & 1.165 \\
\hline$F S$ & & 0.0001 & 0.270 & 1.362 \\
\hline IPI & + & 0.0083 & $5.948 * * *$ & 1.166 \\
\hline
\end{tabular}

Table 17 Parameter estimates (t-statistics) from time regression results

All tests are one-tailed: ${ }^{*} \mathrm{p}<=0.10, * * \mathrm{p}<=0.05, * * \mathrm{p}<=0.01$.

\subsubsection{BT and PFP}

To explore whether the market reaction to the BT is moderated by the firm's prior financial performance, we estimate the following regression model with reference to Jacobs and Singhal (2014): 


$$
\begin{gathered}
A_{i 0}=\beta_{0}+\beta_{1} I L W R+\beta_{2} B T+\beta_{3} C O+\beta_{4} P F P \\
+\beta_{4 a}\left(B T \cdot P F P^{\prime}\right)+\beta_{5} F S T+\beta_{6} F S+\varepsilon_{i}
\end{gathered}
$$

where $B T \cdot P F P^{\prime}$ is the interaction between prior financial performance and $B T$; $P F P^{\prime}$ is an indicator variable that is 1 if the company's PFP is greater than the median of all sample companies and 0 otherwise. Table 18 presents the parameter estimates (t-values in parentheses) for the regression model in Equation (11). The results indicate that the coefficients for $P F P$ and $B T$ are still insignificant. However, the coefficient for $B T \cdot P F P^{\prime}$ is statistically significant (at the $5 \%$ level).

To obtain a clearer interpretation of the regression results from Equation (11), Figure 3 plots the regression lines for the abnormal returns as a function of the firm's prior financial performance, which is conditioned on the two kinds of companiesLSC and LESMC. For LSC (i.e., $B T=0$ ), the abnormal returns are increasing in the PFP (slope is 0.011). When LSCs have a financial performance equal to that of industries (i.e., $P F P=0$ ), the model predicts that the day 0 abnormal return is $0.7 \%$. However, for LESMCs, the abnormal returns are decreasing in the PFP (slope is 0.078). At $P F P=0$, the model predicts that the day 0 abnormal return is $0.38 \%$. The evidence suggests that the market reaction as a function of the BT is strongly moderated by the firm's prior financial performance, which verifies hypothesis 7 and supports hypothesis 6 .

\begin{tabular}{|c|c|c|c|c|}
\hline $\mathrm{R}^{2}$ & Adjusted $\mathrm{R}^{2}$ & Durbin-Watson value & F-value & $\mathrm{N}$ \\
\hline \multicolumn{5}{|c|}{ Panel A: Interaction Model } \\
\hline $3.9 \%$ & $3.3 \%$ & 1.723 & $7.118 * * *$ & 1248 \\
\hline Variable & expectation & Parameter & T-value & VIF \\
\hline \multicolumn{5}{|c|}{ Panel B: Parameter Estimates } \\
\hline$\beta_{0}$ & & -0.0110 & -0.957 & \\
\hline$I L W R$ & + & 0.0026 & $1.732 * *$ & 1.143 \\
\hline$B T$ & - & 0.0031 & 1.2167 & 2.058 \\
\hline$C O$ & + & 0.0077 & $4.599 * * *$ & 1.503 \\
\hline$P F P$ & + & -0.0004 & -0.022 & 1.140 \\
\hline FST & & -0.0009 & -0.639 & 1.135 \\
\hline FS & & 0.0005 & 0.971 & 1.366 \\
\hline$B T \cdot P F P^{\prime}$ & & -0.0073 & $-2.157 * *$ & 1.876 \\
\hline
\end{tabular}

Table 18 Parameter estimates (t-statistics) from interaction regression results

All tests are one-tailed: $*_{\mathrm{p}}<=0.10, * *_{\mathrm{p}}<=0.05, * * *^{\mathrm{p}}<=0.01$. 


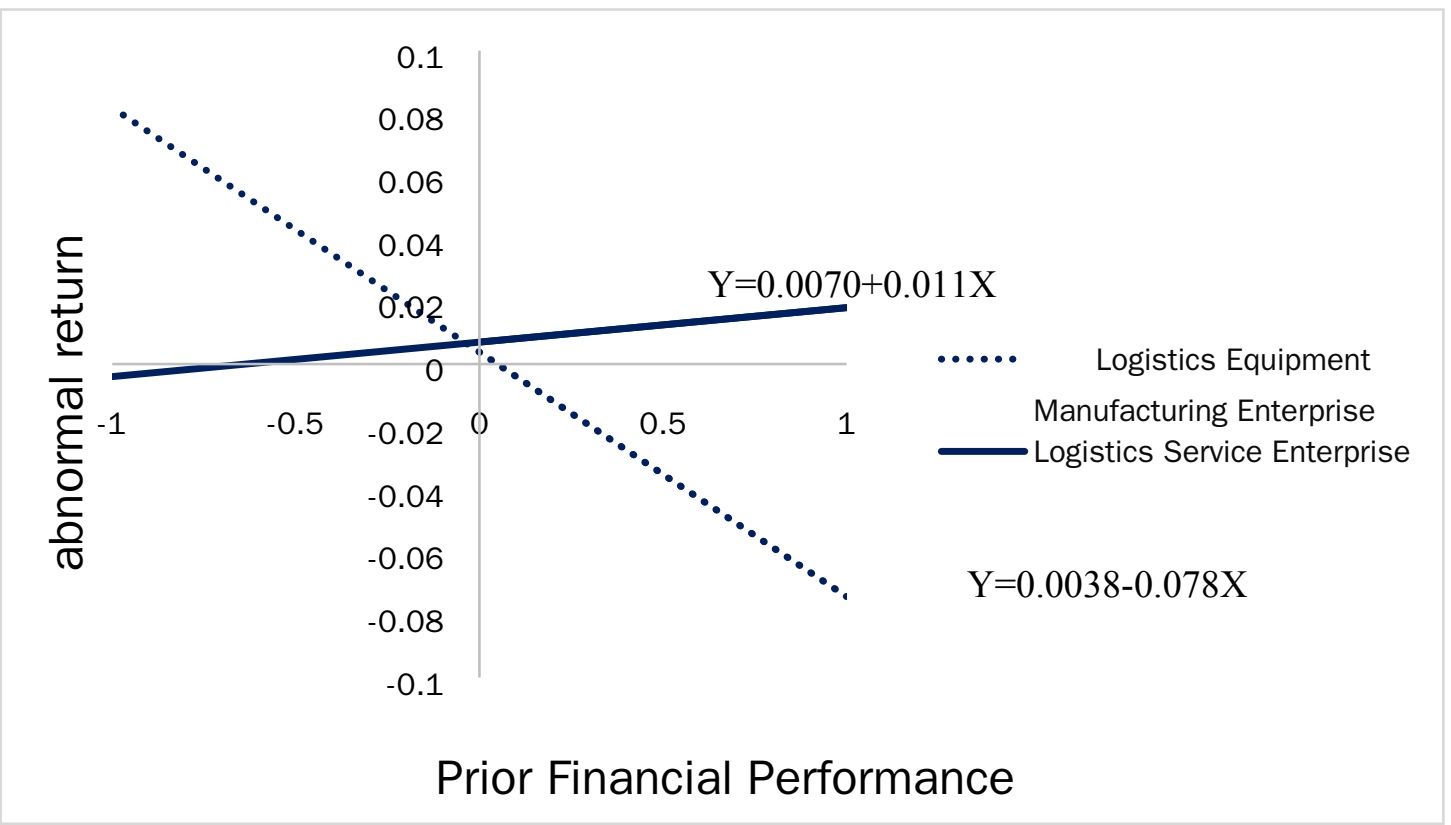

Fig. 3 Relationship between the abnormal returns and PFP of different types of companies

We find that for a logistics service company, when its PFP is better, its shareholder value will be more positively affected by ILPs than that when its PFP is worse; and for a LESMC, when its PFP is worse, its shareholder value will be more positively affected than that when its PFP is better.

This conclusion is new and counter intuitive because many researchers have shown that companies that always perform better will have a more positive market reaction to external positive events (such as policy support, awards, etc.) (Xia et al., 2016). The reason for this conclusion is closely related to the current development of Chinese intelligent logistics industry: in China, logistics service is a relatively mature industry but the intelligent logistics equipment manufacturing industry is still in a growing period.

In the mature logistics service industry, the market reaction of the company with good PFP is more positive because the competition is fierce in the mature industry, and only companies with a good PFP can have greater profit and development space; therefore, the market capital is more inclined to the company with a good PFP. In the immature intelligent logistics equipment manufacturing industry, the market reaction of the company with a poor PFP is more positive because the competition is relatively low among growing industries regardless of whether the PFP is good or bad because of the many development opportunities for companies. Many companies with poor PFP are very likely to increase their performance in a short period. Investing in these 
companies can lead to more profits in a short time. Therefore, market capital tends to flow towards companies with a poor PFP. This conclusion is similar to that of previous studies, which can be described as an interaction effect. This theory holds that companies with different performance may have opposite reactions to the same thing (Jacobs and Singhal, 2014; Li et al., 2019a). Our research shows that the interaction effects are still valid in the stock market reaction of policies.

\subsubsection{Service breadth of the logistics service companies}

We propose the definition and classification criteria of three types of companies with low, medium and high service breadth in section 4.4.4. Panel A of Table 19 shows statistical descriptions of the abnormal returns of the three types of companies on the event day. The mean (median) of the abnormal returns of $\mathrm{C}_{\mathrm{L}}$ is $1.04 \%(0.65 \%)$, which is significantly greater than 0 at the $1 \%(1 \%)$ level; the mean (median) of the abnormal returns of $\mathrm{C}_{\mathrm{M}}$ is $0.64 \%(0.36 \%)$, which is significantly greater than 0 at the $1 \%(1 \%)$ level; and the mean (median) of the abnormal returns of $\mathrm{C}_{\mathrm{H}}$ is $0.17 \%$ $(0.14 \%)$, which is insignificantly different from zero. We perform the F-test (joint hypotheses test) to better compare the differences among the three types of companies. Panel B of Table 19 shows that the significance is $0.168(>0.05)$ and the F value is 12.576 , which are statistically significant at the $1 \%$ level, indicating that there are significant differences between at least two groups of data. The abnormal returns of $C_{L}$ are different from that of $C_{H}$ at the $1 \%$ level, while those of $C_{M}$ are different from that of $\mathrm{C}_{\mathrm{L}}$ and $\mathrm{C}_{\mathrm{H}}$ at the $5 \%$ level. The market reaction of $\mathrm{C}_{\mathrm{L}}$ is the largest, followed by $\mathrm{C}_{\mathrm{M}}$ and $\mathrm{C}_{\mathrm{H}}$. Unexpectedly, this is exactly the opposite of our hypothesis; therefore, we reject hypothesis 8 . This finding shows that although companies with high service breadth will have more resources, the market still believes that companies with only a single service link (warehousing, transportation, distribution) can take the lead in the breakthrough of intelligent logistics because their business is more focused and the application of intelligent technology is more convenient. Thus, intelligent logistics brings the most obvious benefit to them. 
Table 19 T-test and F-test for different service breadth of LSCs

\begin{tabular}{|c|c|c|c|}
\hline \multicolumn{4}{|c|}{ Panel A: One-sample T-test } \\
\hline Company type & $\mathrm{C}_{\mathrm{L}}$ & $\mathrm{C}_{\mathrm{M}}$ & $\mathrm{C}_{\mathrm{H}}$ \\
\hline $\mathrm{N}$ & 505 & 271 & 246 \\
\hline $\begin{array}{l}\text { Mean abnormal } \\
\text { return } / \%\end{array}$ & 1.04 & 0.64 & 0.17 \\
\hline t-statistic & $10.911 * * *$ & $4.430 * * *$ & 1.171 \\
\hline $\begin{array}{l}\text { Median abnormal } \\
\text { return } / \%\end{array}$ & 0.65 & 0.36 & 0.14 \\
\hline $\begin{array}{l}\text { Wilcoxon signed- } \\
\text { rank Z-statistic }\end{array}$ & $11.783 * * *$ & $4.909 * * *$ & 0.895 \\
\hline $\begin{array}{l}\text { Abnormal returns } \\
\text { positive } / \%\end{array}$ & 73 & 65 & 53 \\
\hline $\begin{array}{l}\text { Binomial sign test Z- } \\
\text { statistic }\end{array}$ & $10.413 * * *$ & $4.860 * * *$ & 0.956 \\
\hline \multicolumn{4}{|l|}{ Panel B: F-test } \\
\hline significance & & 0.168 & \\
\hline F-value & & $12.576^{* * *}$ & \\
\hline Sign. & $\mathrm{C}_{\mathrm{L}}$ & $\mathrm{C}_{\mathrm{M}}$ & $\mathrm{C}_{\mathrm{H}}$ \\
\hline $\mathrm{C}_{\mathrm{L}}$ & & $0.018 * *$ & $8.2667 \mathrm{E}-7 * * *$ \\
\hline $\mathrm{C}_{\mathrm{M}}$ & $0.018 * *$ & & $0.019 * *$ \\
\hline $\mathrm{C}_{\mathrm{H}}$ & $8.2667 \mathrm{E}-7 * * *$ & $0.019 * *$ & \\
\hline
\end{tabular}

All tests are one-tailed: ${ }^{*} \mathrm{p}<=0.10, * * \mathrm{p}<=0.05, * * * \mathrm{p}<=0.01$.

\subsection{Summary of the Hypothesis Test Results}

According to the analysis in this chapter, we have tested all eight hypotheses and find that $H 1, H 2, H 3-3, H 3-4, H 4$ and $H 5$ are accepted while the other hypotheses are rejected. 
Table 20 Summary of hypothesis test results

\begin{tabular}{llr}
\hline No. & Result & Remarks \\
\hline$H 1$ & Accepted & \\
$H 2$ & Accepted & \\
$H 3-1$ & Rejected & The market reaction by policies of NDRC are more positive than that by \\
$H 3-2$ & Rejected & policies of the State Council and MOT \\
$H 3-3$ & Accepted & \\
$H 3-4$ & Accepted & \\
$H 4$ & Accepted & \\
$H 5$ & Accepted & \\
$H 6$ & Rejected & For an LSC, when its PFP is better, its shareholder value will be more \\
& & positively affected by the ILP than that when its PFP is worse; for a \\
& & LESMC, when its PFP is worse, its shareholder value will be more \\
& & positively affected than that when its PFP is better. \\
$H 7$ & Rejected & Contrary to our expectation, the market reaction of the company will \\
& & decrease with the increase of its service breadth. \\
\hline
\end{tabular}

From Table 20,H1, H2, H3-3, H3-4, H4 and H5 are consistent with our expectations; however, for H3-1 and H3-2, the market reaction by policies of NDRC are more positive than that by policies of the State Council and MOT. We find an interaction effect in $H 6$ and H7. For an LSC, when its PFP is better, its shareholder value will be more positively affected by the ILP than that when its PFP is worse. For a LESMC, when its PFP is worse, its shareholder value will be more positively affected than that when its PFP is better. Contrary to our expectation, the market reaction of the company will decrease with the increase of its service breadth according to $H 8$.

\section{Conclusions and Managerial Implications}

\subsection{Conclusions}

Based on 20 intelligent logistics policies issued by the Chinese government in the past five years from 2013 to 2018, this paper explores how intelligent logistics policies affect the operating performance of 149 listed logistics companies in China. The results show that the mean (median) abnormal return on the event day is $0.625 \%$ $(0.352 \%)$, and the value is greater than 0 at the level of $1 \%$. The average positive rate is $63 \%$, which is significantly higher than $50 \%$. We can see that the ILP will result in 
a positive stock market reaction. In addition, 1) the market reaction will be more positive with the increase of the proportion of the intelligent logistics contents and the policies issued by the State Council and the General Office as the leader will produce fewer positive reactions than that by the subordinate ministries. The impact of the NDRC is the greatest. Moreover, jointly released policies often have a better effect while a centralized release is not a good choice. 2) ILPs have a more positive impact on the market value of state-owned enterprises, and the lower the service breadth of enterprises, the more positively the market reacts for all logistics companies. 3) For an LSC, when its PFP is better, its shareholder value will be more positively affected by the ILP than that when its PFP is worse. For a LESMC, when its PFP is worse, its shareholder value will be more positively affected than that when its PFP is better.

\subsection{Managerial Implications}

This paper provides empirical implication for the future research and decisionmaking of the government and companies.

\subsubsection{Theoretical implications}

To our best knowledge, this study is the first to analyze the effects of ILPs on the stock market by the event study method. We investigate the short-term market reaction of the companies during the event windows of policy release, providing a new perspective for studying and evaluating policies. From the perspective of government and companies, this study discusses the influence of various factors such as policy release modes and company types on the market reaction of logistics policies, which provides a model to study the effects of industry policies on the stock market.

The conclusions of this paper confirm and enrich some research theories. For example, institutional theory holds that the functions of government departments are different. It's commonly known that departments with higher power have greater influence on social economy (Kong, 2019). We find that the General Office of the State Council, which is the leading agency, has a lower impact than its subordinate ministries. This conclusion shows that institutional theory has particularity in the economy. The ministries with less power but closer responsibilities may have more influence in certain industries. In addition, we find that LSCs are more positive when their financial performances are better, while the opposite result is observed for LESMCs. This phenomenon verifies the interaction effects. This theory holds that companies with different performance may have opposite reactions to the same thing (Jacobs and Singhal, 2014; Li et al., 2019a). Our research shows that the interaction 
effects are still valid in the stock market reaction of policies, which expands the scope of this theory.

\subsubsection{Practical implications for government}

According to $H 1$ and $H 2$, ILPs have a positive impact on the logistics market. When the government pays more attention to intelligent logistics, the proportion of the policy content about intelligent logistics will be greater and the market reaction will be more positive. These findings show that intelligent logistics is a trend of logistics, which can prompt the government to enhance the strategic goals of intelligent logistics and use macro-control to promote the development of intelligent logistics. The government should release some special intelligent logistics policies instead of just a few clauses to stimulate market vitality.

According to H3-1, H3-2 and H3-3, the influence of the State Council and the General Office is inferior to that of the NDRC because the policies of the General Office usually clarify the tasks of the ministries and stipulate the direction of development while policies issued by the ministries are more specific and conducive to the implementation of enterprises. Therefore, the government should fully consider the practice of implementing policies and make more detailed provisions so that the market can obtain policy dividends. At the same time, they should pay more attention to the role of the NDRC in the development of intelligent logistics. It is suggested that NDRC should set up a working group to take charge of intelligent logistics.

According to H3-4 and $H 4$, which are focused on the release mode, we find that all ministries should strengthen their cooperation to jointly issue policies, which will have a more positive impact on the market. Moreover, when policies are issued centrally, the market will not react very positively to the subsequent policies and the effect will be weakened. Because a regulatory ceiling is observed under continuous policy promotion in a certain period, the government should pay more attention to choosing the right time to avoid centralized policy release and increasing the quality of the policy rather its quantity.

According to $H 8$, considering intelligent logistics is still at the initial stage in China, and the government should give priority to the intelligent construction of logistics services in transportation, warehousing, distribution and other basic procedures, which can not only improve the market reaction to ILPs but also effectively lay a solid foundation for the systematic construction of intelligent logistics. Governments should support more for these basic procedures in terms of capital, talent and land. 


\subsubsection{Practical implications for managers}

According to $\mathrm{H5}$, we find that state-owned enterprises receive a more positive market reaction than non-state-owned enterprises. When the government actively develops the intelligent logistics, state-owned capital as a manifestation of the government plays a role of leading the development of intelligent logistics. Stateowned enterprises have institutional advantages in developing intelligent logistics. Therefore, state-owned logistics enterprises should take measures to innovate bravely and lead the development of the logistics industry in the future.

According to $H 6, H 7$ and section 5.3.3, for an LSC, when its PFP is better, its shareholder value will be more positively affected by the ILP than that when its PFP is worse. For a LESMC, when its PFP is worse, its shareholder value will be more positively affected than that when its PFP is better. These findings provide managerial implications for these companies. LSCs should closely follow the government orientation when their performance is good and try their best to respond to the policy to expand their own advantages and achieve greater development. LESMCs should pay close attention to government guidance to actively adjust their product range, optimize the quality and turn losses into profits.

According to $H 8$, we find that logistics companies with a low service breadth have more positive market reaction. Therefore, in the process of developing intelligent logistics, enterprises should gradually develop it more comprehensively. They should first pay attention to upgrading and innovating their basic business, such as warehousing, transportation and distribution, and then consider integrated intelligent service. It is a good choice for the logistics companies with a low service breadth to develop intelligent logistics to get better performance.

\subsection{Limitations and Future Research Directions}

There are still some limitations in this research that need to be further studied in the future. First, we focus on ILPs and the development of intelligent logistics in China. The results may be more applicable to China or other developing countries but cannot be fully extended to all countries. Therefore, we can study the logistics markets of developed countries based on the ideas of this paper in the future. Second, we use the ILWR as the criterion to measure the degree of the policy's concern about intelligent logistics, which is not detailed enough. In the future, we can perform policy text mining to analyze the role of some key words to predict the development direction of intelligent logistics. Third, this paper mainly focuses on how the government affects the development of intelligent logistics but does not reflect 
corporate behavior. In the future, we can explore intelligent logistics by studying product development and announcements. Finally, all the data used in this research are secondary data which were derived from the RESSET database, but not from a survey. We can explore new methods to verify the findings of secondary data with interviews with managers in future.

\section{References}

Adamski, A., 2011. Hierarchical Integrated Intelligent Logistics System Platform. Procedia Social and Behavioral Sciences, 20, 1004-1016.

Asongu, S.A., 2012. Government quality determinants of stock market performance in African countries. Journal of African Business, 13(3), 183-199.

Aziza, F.O., 2010. The effects of monetary policy on stock market performance: A cross-country analysis. Available at SSRN: https://ssrn.com/abstract=1743834 or http://dx.doi.org/10.2139/ssrn.1743834

Barber, B.M., Lyon, J.D., 1996. Detecting abnormal operating performance: The empirical power and specification of test statistics. Journal of financial Economics, 41(3), 359-399.

Brandon-Jones, E., Dutordoir, M., Neto, J.Q.F., \& Squire, B., 2017. The impact of reshoring decisions on shareholder wealth. Journal of Operations Management, 49, 31-36.

Brogaard, J., \& Detzel, A., 2015. The asset-pricing implications of government economic policy uncertainty. Management Science, 61(1), 3-18.

Brown, S.J., Warner, J.B., 1985. Using daily stock returns: The case of event studies. Journal of financial economics, 14(1), 3-31.

Chatziantoniou, I., Duffy, D., \& Filis, G., 2013. Stock market response to monetary and fiscal policy shocks: Multi-country evidence. Economic Modelling, 30, 754-769.

Chen, Q., Xu, X., Cao, B., et al., 2016. Social media policies as responses for social media affordances: The case of China. Government Information Quarterly, 33(2), 313-324.

Cho, D.W., Lee, Y.H., Ahn, S.H., et al., 2012. A framework for measuring the performance of service supply chain management. Computers \& Industrial Engineering, 62(3), 801-818.

Choi, T.M., Wallace, S.W., \& Wang, Y. (2018). Big data analytics in operations management. Production and Operations Management, 27(10), 1868-1883.

Corbett, C.J., Montes-Sancho, M.J. and Kirsch, D.A., 2005. The financial impact of ISO 9000 certification in the United States: An empirical analysis. Management Science, Vol. 51 No. 7, pp. 1046-1059.

Cull, R., Xu, L.C., 2003. Who gets credit? The behavior of bureaucrats and state banks in allocating credit to Chinese state-owned enterprises. Journal of Development Economics, 71(2), 533-559.

Dacin, M.T., Goodstein, J., \& Richard, S.W., 2002. Institutional theory and institutional change: Introduction to the special research forum. Academy of Management Journal, 45(1), 45-56. 
Ding, L., Lam, H.K.S., Cheng, T.C.E., et al., 2018. A review of short-term event studies in operations and supply chain management. International Journal of Production Economics, 200, 329-342.

Docherty, I., Marsden, G., \& Anable, J., 2018. The governance of smart mobility. Transportation Research Part A: Policy and Practice, 115, 114-125.

Donald, J., Bowersox, C., David, J., \& Cooper, M., 2012. Supply chain logistics management. McGraw-Hill Education.

Fan, F.F., 2019. Deliveries turn smart, super quick. Available at: < https://www.chinadaily.com.cn/a/201911/11/WS5dc8b91ea310cf3e35576866.html> (accessed 11 Nov. 2019)

Ferro, E., Loukis, E.N., Charalabidis, Y., et al., 2013. Policy making 2.0: From theory to practice. Government Information Quarterly, 30(4), 359-368.

Gao, X., Ren, Y., \& Li, X., 2019. The interdependence of global oil price, China's stock price and economic policy uncertainty. Australian Economic Papers, 58(4), 398-415.

Govindan, K., Cheng, T.C.E., Mishra, N., et al., 2018. Big data analytics and application for logistics and supply chain management. Transportation Research Part E: Logistics and Transportation Review, 114, 343-349.

Hendricks, K.B., Singhal, V.R., 2003. The effect of supply chain glitches on shareholder wealth. Journal of operations Management, 21(5), 501-522.

Hendricks, K.B., Singhal, V.R., 2005. Association between supply chain glitches and operating performance. Management Science, Vol. 51 No. 5, pp. 695-711.

Hendricks, K.B., Singhal, V.R., Zhang, R., 2009. The effect of operational slack, diversification, and vertical relatedness on the stock market reaction to supply chain disruptions. Journal of operations management, 27 (3), 233-246.

Hendricks, K.B., Hora, M., and Singhal, V.R., 2014. An empirical investigation on the appointments of supply chain and operations management executives. Manage. Sci. 61(7), 1562-1583.

Hendricks, K.B., Jacobs, B.W., Singhal, V.R., 2019. Stock market reaction to supply chain disruptions from the 2011 Great East Japan Earthquake. Manufacturing \& Service Operations Management. https://doi.org/10.1287/msom.2019.0777

Iqbal, Z., Shetty, S., 1995. Layoffs, stock price, and financial condition of the firm. Journal of Applied Business Research, 11(2), 67.

Jabeur, N., Al-Belushi, T., Mbarki, M., et al., 2017. Toward Leveraging Smart Logistics Collaboration with a Multi-Agent System Based Solution. Procedia Computer Science, 109, 672-679.

Jacobs, B.W., Singhal, V.R., \& Subramanian, R., 2010. An empirical investigation of environmental performance and the market value of the firm. Journal of Operations Management, 28(5), 430-441. 
Jacobs, B.W., Singhal, V.R., 2014. The effect of product development restructuring on shareholder value. Production and Operations Management, 23(5), 728-743.

Kagermann, H., Wahlster, W., Helbig, J., 2013. Securing the future of German manufacturing industry. Recommendations for implementing the strategic initiative INDUSTRIE, 4(199), 14.

Kang, W., \& Ratti, R.A., 2013. Oil shocks, policy uncertainty and stock market return. Journal of International Financial Markets, Institutions and Money, 26, 305-318.

Karim, M.A., 2003. Technology and improved service delivery: Learning points from the Malaysian experience. International Review of Administrative Sciences, 69(2), 191-204.

Kaustia, M., Knüpfer, S., \& Torstila, S., 2016. Stock ownership and political behavior: evidence from demutualizations. Management Science, 62(4), 945-963.

Kavussanos, M.G., \& Marcoulis, S.N., 1997. The stock market perception of industry risk and microeconomic factors: The case of the US water transportation industry versus other transport industries. Transportation Research Part E: Logistics and Transportation Review, 33(2), 147158.

Kirch, M., Poenicke, O., Richter, K., 2017. RFID in Logistics and Production-Applications, Research and Visions for Smart Logistics Zones. Procedia Engineering, 178, 526-533.

Klassen, R.D., McLaughlin, C.P., 1996. The impact of environmental management on firm performance. Management Science, 42 (8), 1199-1214.

Kong, L., 2019. Government spending and corporate innovation. Management Science. https://doi.org/10.1287/mnsc.2018.3252

Koussouris, S., Lampathaki, F., Kokkinakos, P., et al., 2015. Accelerating Policy Making 2.0: Innovation directions and research perspectives as distilled from four standout cases. Government Information Quarterly, 32(2), 142-153.

Lam, H.K.S., Yeung, A.C.L., Cheng, T.C.E., Humphreys, P.K., 2016. Corporate environmental initiatives in the Chinese context: performance implications and contextual factors. International Journal of Production Economics, 180, 48-56.

Lepak, G.M., 1997. Airline deregulation and the impact on stock prices of major surviving carriers. Transportation Research Part E: Logistics and Transportation Review, 33(2), 107-115.

Li, G., Li, L., Choi, T.M., \& Sethi, S.P., 2019a. Green supply chain management in Chinese firms: Innovative measures and the moderating role of quick response technology. Journal of Operations Management. https://doi.org/10.1002/joom.1061

Li, S., Song, X., Wu, H., 2015. Political connection, ownership structure, and corporate philanthropy in China: A strategic-political perspective. Journal of Business Ethics, 129(2), $399-411$.

Li, S., Sui, P. C., Xiao, J., \& Chahine, R., 2019b. Policy formulation for highly automated vehicles: Emerging importance, research frontiers and insights. Transportation Research Part A: Policy and Practice, 124, 573-586.

Li, X., 2015. Innovation center promotes advances in logistics. Available at: < 
http://www.chinadaily.com.cn/world/2015-05/20/content_20776112.htm> (accessed 20 May. 2015)

Liang, H., Saraf, N., Hu, Q., \& Xue, Y., 2007. Assimilation of enterprise systems: The effect of institutional pressures and the mediating role of top management. MIS Quarterly, 31(1), 5987.

Lin, C.-S., Su, C.-T., 2013. The Taiwan national quality award and market value of the firms: an empirical study. International Journal of Production Economics, 144 (1), 57-67.

Liu, W., Wang, D., Zhao, X., et al., 2019. The framework for designing new logistics service product: a multi-case investigation in China. Asia Pacific Journal of Marketing and Logistics, https://doi.org/10.1108/APJML-12-2017-0338.

Liu, X., Zheng, L., 2015. Cross-departmental collaboration in one-stop service center for smart governance in China: Factors, strategies and effectiveness. Government Information Quarterly, 35(4), 54-60.

Magalhaes, G., Roseira, C., 2017. Open government data and the private sector: an empirical view on business models and value creation. Government Information Quarterly, https://doi.org/10.1016/j.giq.2017.08.004.

Martin, C., Lynette, R., 1999. Supply chain strategy: its impact on shareholder value. The international journal of logistics management, 10 (1), 1-10.

McFarlane, D., Giannikas, V., \& Lu, W., 2016. Intelligent logistics: Involving the customer. Computers in Industry, 81, 105-115.

McGuire, S.J., Dilts, D.M., 2008. The financial impact of standard stringency: an event study of successive generations of the ISO 9000 standard. International Journal of Production Economics, 113 (1), 3-22.

Montreuil, B., 2011. Toward a Physical Internet: meeting the global logistics sustainability grand challenge. Logistics Research, 3(2-3), 71-87.

Mosley, L., \& Singer, D.A., 2008. Taking stock seriously: Equity-market performance, government policy, and financial globalization. International Studies Quarterly, 52(2), 405425.

MOT, 2013. Guiding Opinions on Promoting the Intelligent Development of Transportation Informatization.

Available

at:

$<$ http://xxgk.mot.gov.cn/jigou/kjs/201309/t20130930_2975104.html> (accessed 30 Sept. 2013) (in Chinese).

NDRC, 2016a. "Internet +" Efficient Logistics Implementation Opinions. Available at: $<$ http://zfxxgk.ndrc.gov.cn/web/iteminfo.jsp?id=2535> (accessed 29 Jul. 2016) (in Chinese).

NDRC, 2016b. Promoting "Internet +" Convenient Transportation to Promote the Development of Intelligent Transportation. Available at: $<$ http://zfxxgk.ndrc.gov.cn/web/iteminfo.jsp?id=2538> (accessed 30 Jul. 2016) (in Chinese).

Oh, J., Jeong, B., 2019. Tactical supply planning in smart manufacturing supply chain. Robotics 
and Computer-Integrated Manufacturing, 55, 217-233.

Pastor, L., \& Veronesi, P., 2012. Uncertainty about government policy and stock prices. The journal of Finance, 67(4), 1219-1264.

Raza, A., Ahmed, Z., Ahmed, M., \& Ahmed, T., 2012. The role of FDI on stock market development: the case of Pakistan. Journal of Economics and Behavioral Studies, 4(1), 26-33.

Porta, R.L., Lopez-de-Silanes, F., Shleifer, A., \& Vishny, R. W. (1998). Law and finance. Journal of political economy, 106(6), 1113-1155.

Sarkis, J., Gonzalez-Torre, P., \& Adenso-Diaz, B., 2010. Stakeholder pressure and the adoption of environmental practices: The mediating effect of training. Journal of Operations Management, 28(2), 163-176.

Seufert, J.H., Arjomandi, A., \& Dakpo, K.H., 2017. Evaluating airline operational performance: A Luenberger-Hicks-Moorsteen productivity indicator. Transportation Research Part E: Logistics and Transportation Review, 104, 52-68.

Shams, S.M.M., Gunasekarage, A., 2016. Operating performance following corporate acquisitions: Does the organisational form of the target matter?. Journal of Contemporary Accounting \& Economics, 12(1), 1-14.

Sims, E.N., 1986. The Council of State Governments: A national information provider. Government Information Quarterly, 3(4), 407-417.

Speranza, M.G., 2018. Trends in transportation and logistics. European Journal of Operational Research, 264(3), 830-836.

State Council, 2014. Medium and long-term planning for the development of logistics industry (2014-2020). Available at: <http://www.gov.cn/zhengce/content/201410/04/content_9120.htm> (accessed 4 Oct. 2014) (in Chinese).

State Council, 2016. Notice on Forwarding the Special Action Plan for the Reduction and Efficiency of Logistics Industry (2016-2018). Available at: $<$ http://www.gov.cn/zhengce/content/2016-09/26/content_5112169.htm> (accessed 26 Sept. 2016) (in Chinese).

Tambe, P., 2014. Big Data Investment, Skills, and Firm Value. Management Science, 60(6), 14521469.

Thomas, A., 2001. Corporate environmental policy and abnormal stock price returns: an empirical investigation. Business strategy and the Environment, 10(3), 125-134.

Tjahjono, B., Esplugues, C., Ares, E., et al., 2017. What does Industry 4.0 mean to Supply Chain?. Procedia Manufacturing, 13, 1175-1182.

Torres, L., 2005. Service charters: Reshaping trust in government-the case of Spain. Public Administration Review, 65(6), 687-699.

Uckelmann, D., 2008. A definition approach to smart logistics. In: International Conference on Next Generation Wired/Wireless Networking. Springer, Berlin, Heidelberg, pp. 273-284.

Wang, H., Qian, C., 2011. Corporate philanthropy and corporate financial performance: The roles 
of stakeholder response and political access. Academy of Management Journal, 54(6), 11591181.

Worrell, D.L., Davidson, W.N., Sharma, V.M., 1991. Layoff announcements and stockholder wealth. Academy of Management Journal, 34(3), 662-678.

Xia, Y., Singhal, V.R., Peter Zhang, G., 2016. Product design awards and the market value of the firm. Production and Operations Management, 25(6), 1038-1055.

Yang, Y., 2019. Alibaba to invest $4.66 \mathrm{~b}$ yuan in smart logistics. Available at: < https://www.chinadaily.com.cn/a/201903/11/WS5c8627f1a3106c65c34edfc1.html> (accessed 11 Mar. 2019)

Yang, Y., Zhang, X., Lee, P.K.C., 2019. Improving the effectiveness of online healthcare platforms: An empirical study with multi-period patient-doctor consultation data. International Journal of Production Economics, 207, 70-80.

Yu, S., Lee, N., 2016. Financial crisis, politically connected CEOs, and the performance of stateowned enterprises: evidence from Korea. Emerging Markets Finance and Trade, 52(9), 20872099.

Zhao, X., Li, Y., Flynn, B.B., 2013. The financial impact of product recall announcements in China. International Journal of Production Economics, 142 (1), 115-123.

Zhou, M., Park, T., Yi, J., 2009. Commonalities and differences between service and manufacturing supply chains: Combining operations management studies with supply chain management. California Journal of Operations Management, 7(1): 136. 


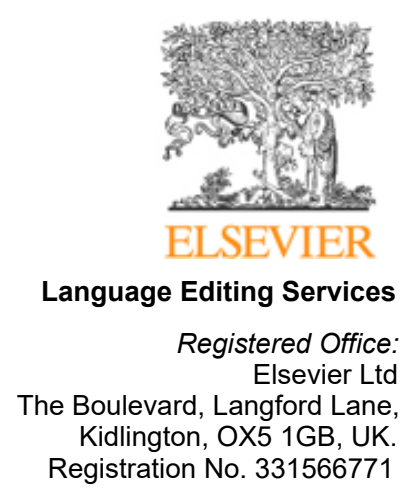

To whom it may concern

The paper "Effect of Intelligent Logistics Policy on Shareholder Value: Evidence from Chinese Logistics Companies" by Authors was edited by Elsevier Language Editing Services.

Kind regards,

\section{Elsevier Webshop Support}




\section{Author statement}

Weihua Liu: Supervision, make the modification of response to reviewers' comments

Siyu Wang: Writing-Original draft preparation and response

Yong Lin: Conceptualization, Methodology, Software

Dong Xie: Writing- Reviewing and Editing

Jiahui Zhang: Revising introduction and hypothesis development, Editing 